\title{
Cloud condensation nuclei production associated with atmospheric nucleation: a synthesis based on existing literature and new results
}

\author{
V.-M. Kerminen ${ }^{1}$, M. Paramonov ${ }^{1}$, T. Anttila ${ }^{2}$, I. Riipinen ${ }^{3}$, C. Fountoukis ${ }^{4}$, H. Korhonen ${ }^{5}$, E. Asmi ${ }^{2}$, L. Laakso ${ }^{2}$, \\ H. Lihavainen ${ }^{2}$, E. Swietlicki ${ }^{6}$, B. Svenningsson ${ }^{6}$, A. Asmi ${ }^{1}$, S. N. Pandis ${ }^{4}$, M. Kulmala ${ }^{1}$, and T. Petäjä ${ }^{1}$ \\ ${ }^{1}$ Department of Physics, University of Helsinki, 00014 Helsinki, Finland \\ ${ }^{2}$ Finnish Meteorological Institute, Research and Development, 00101 Helsinki, Finland \\ ${ }^{3}$ Department of Applied Environmental Science \& Bert Bolin Centre for Climate Research, Stockholm University, 11418, \\ Stockholm, Sweden \\ ${ }^{4}$ Institute of Chemical Engineering Sciences, Foundation for Research and Technology Hellas (ICEHT/FORTH), Patras, \\ Greece \\ ${ }^{5}$ Finnish Meteorological Institute, Kuopio Unit, P.O. Box 1627, 70211 Kuopio, Finland \\ ${ }^{6}$ Division of Nuclear Physics, Lund University, P.O. Box 118, 22100 Lund, Sweden
}

Correspondence to: V.-M. Kerminen (veli-matti.kerminen@fmi.fi)

Received: 14 August 2012 - Published in Atmos. Chem. Phys. Discuss.: 28 August 2012

Revised: 4 December 2012 - Accepted: 4 December 2012 - Published: 19 December 2012

\begin{abstract}
This paper synthesizes the available scientific information connecting atmospheric nucleation with subsequent cloud condensation nuclei $(\mathrm{CCN})$ formation. We review both observations and model studies related to this topic, and discuss the potential climatic implications. We conclude that $\mathrm{CCN}$ production associated with atmospheric nucleation is both frequent and widespread phenomenon in many types of continental boundary layers, and probably also over a large fraction of the free troposphere. The contribution of nucleation to the global CCN budget spans a relatively large uncertainty range, which, together with our poor understanding of aerosol-cloud interactions, results in major uncertainties in the radiative forcing by atmospheric aerosols. In order to better quantify the role of atmospheric nucleation in $\mathrm{CCN}$ formation and Earth System behavior, more information is needed on (i) the factors controlling atmospheric $\mathrm{CCN}$ production and (ii) the properties of both primary and secondary $\mathrm{CCN}$ and their interconnections. In future investigations, more emphasis should be put on combining field measurements with regional and large-scale model studies.
\end{abstract}

\section{Introduction}

Interactions between atmospheric aerosol particles and clouds constitute the largest uncertainty in estimating the current radiative forcing of the Earth's atmosphere (e.g. Forster et al., 2007; Quaas et al., 2009; Koch and Del Genio, 2010; Penner et al., 2011), making it very difficult to predict future climate change (Schwartz et al., 2010). In regional scales, aerosol particles are capable of modifying several cloud properties relevant to both climate and our everyday life. These include cloud microphysical properties (e.g. Mccomiskey et al., 2009; Shao and Liu, 2009), cloud cover and lifetime (e.g. Kaufman and Koren, 2006; Small et al., 2009), and the probability of clouds precipitating (Rosenfeld et al., 2008; Khain, 2009; Sorooshian et al., 2009; Stevens and Feingold, 2009).

The key aerosol property affecting their interaction with warm clouds is the cloud condensation nuclei $(\mathrm{CCN})$ spectrum, i.e. the number concentration of $\mathrm{CCN}$ as a function of water vapor saturation ratio. During the last few decades, $\mathrm{CCN}$ number concentrations and spectra have been measured in a large variety of environments (e.g. Twomey, 1959; Squires and Twomey, 1966; Hobbs et al., 1980; Hudson, 1993; Snider and Brenquier, 2000; Bigg and Leck, 2001; Delene and Deshler, 2001; Hudson and Yum, 2002; Roberts et 
al., 2006; Detwiler et al., 2010). Such studies have brought us plenty of insight into the spatial and temporal variability of the CCN concentration and its dependence on bulk aerosol properties, such as the total particle number concentration and aerosol optical properties (Andreae, 2009; Jefferson, 2010).

Recent developments in size resolved chemical measurements have allowed for detailed investigations between the $\mathrm{CCN}$ spectrum, aerosol number size distribution, and sizeresolved chemical composition of the aerosol. Several investigators have discussed the relative importance of the particle size and chemical composition in determining its capability to act as CCN (Dusek et al., 2006; Hudson, 2007; Kuwata and Kondo, 2008; Quinn et al., 2008; Twohy and Anderson, 2008), while others have studied the role of aerosol mixing state in determining its $\mathrm{CCN}$ properties (e.g. Ervens et al., 2010; Kammermann et al., 2010; Rose et al., 2010; Wang et al., 2010; Wex et al., 2010). In general, these investigations demonstrate that the particle number size distribution is the most important quantity in determining the $\mathrm{CCN}$ number concentration, followed by the aerosol chemical composition. The aerosol mixing state is important close to major anthropogenic source areas.

Understanding the relation between aerosol and their precursor emissions, atmospheric aerosol particle populations, clouds and, eventually, climate is not possible without quantification of the sources responsible for atmospheric CCN (Andreae and Rosenfeld, 2008; Carslaw et al., 2010). One such source is atmospheric nucleation and subsequent growth of nucleated clusters to larger sizes. Model investigations have demonstrated nucleation to be an important source of CCN in the global atmosphere (Spracklen et al., 2008a; Merikanto et al., 2009; Yu and Luo, 2009; Kazil et al., 2010; Luo and $\mathrm{Yu}, 2011 \mathrm{a})$. Field experiments have also shown substantial local enhancements in CCN concentrations due to atmospheric nucleation (e.g. Wiedensohler et al., 2009; Sihto et al., 2011; Yue et al., 2011). No analysis combining these two types of investigations has been performed so far, as a result of which we lack a proper view on the role of nucleation in providing new $\mathrm{CCN}$ in different atmospheric environments.

In this paper, we will synthesize the existing knowledge on $\mathrm{CCN}$ production associated with atmospheric nucleation. In addition to reviewing the published literature on this topic, we will present new experimental data and model results. We will start our analysis by looking at the connection between nuclei growth and their ability to act as CCN (Sect. 2). After that we will review the existing observations on $\mathrm{CCN}$ production resulting from atmospheric nucleation, and present some new data representing long-term observations at a few measurement locations (Sect. 3). In Sect. 4 we will review the existing model simulations of atmospheric $\mathrm{CCN}$ production from nucleation. Concluding remarks and outlook for future work will then be presented in Sect. 5 .
Before starting our analysis, it is worth keeping in mind that, in a broad sense, atmospheric $\mathrm{CCN}$ production can be though to originate from three different sources: i) those resulting from "regional nucleation" taking place in the atmosphere, ii) those resulting from nucleation taking place in the immediate vicinity of localized sources like power plants or cloud outflow regions, and iii) those resulting from the atmospheric processing of primary aerosol particles that are originally too small to act as CCN. Current large-scale models have major problems in capturing the second of these source categories, usually counting those particles as primary $\mathrm{CCN}$. Partly because of this, we will constrain our analysis to the first of the above source categories, but discuss also briefly the second source category in Sects. 3.1 and 5.2. CCN resulting from the atmospheric processing of small primary aerosol particles, while extremely important as well (e.g. Adams and Seinfeld, 2003; Luo and Yu, 2011a), will not be considered here.

\section{Connection between nucleation, $\mathrm{CCN}$ growth and cloud droplet activation}

\subsection{Threshold sizes for atmospheric CCN}

\subsubsection{Theory}

Cloud condensation nuclei (CCN) are defined here as particles that can activate at a given water saturation ratio, $S_{\text {wat }}$. Activation refers to indefinite growth of a particle due to condensation of water vapor at constant $S_{\text {wat }}$. Here we apply the $\kappa$-Koehler theory (Petters and Kreidenweis, 2007) to link physico-chemical properties of particles to their CCN activation ability. Accordingly, the equilibrium saturation ratio of water vapor above the surface of a particle, $S_{e q}$, can be expressed as follows:

$S_{\mathrm{eq}}=\frac{d^{3}-d_{\mathrm{dry}}^{3}}{d^{3}-d_{\mathrm{dry}}^{3}(1-\kappa)} \exp \left(\frac{A}{d}\right)$, where $A=\frac{4 \sigma_{\mathrm{s} / \mathrm{a}} M_{\mathrm{w}}}{R T \rho_{\mathrm{w}}}$

Here $d$ and $d_{\text {dry }}$ are the particle wet and dry sizes, respectively, $\sigma_{s / a}$ is the surface tension of the solution/air interface, $M_{w}$ is the molecular weight of water, $R$ is the universal gas constant, $T$ is temperature, and $\rho_{w}$ is the density of water. The particle water uptake properties are described by the parameter $\kappa$ : larger values of $\kappa$ imply larger hygroscopicity and vice versa. Despite its simplicity, evidence from field, laboratory and modeling studies show that Eq. (1) provides relatively accurate link between the particle size, its chemical composition and CCN activity (Petters and Kreidenweis, 2007; Pringle et al., 2010 and references therein; Rissler et al., 2010).

The critical saturation ratio $S_{\mathrm{c}}$, i.e. the saturation ratio of water vapor needed for a particle with a certain dry size, $d_{\text {dry }}$, to act as $\mathrm{CCN}$, can be found by calculating $S_{\mathrm{eq}}$ as a function 


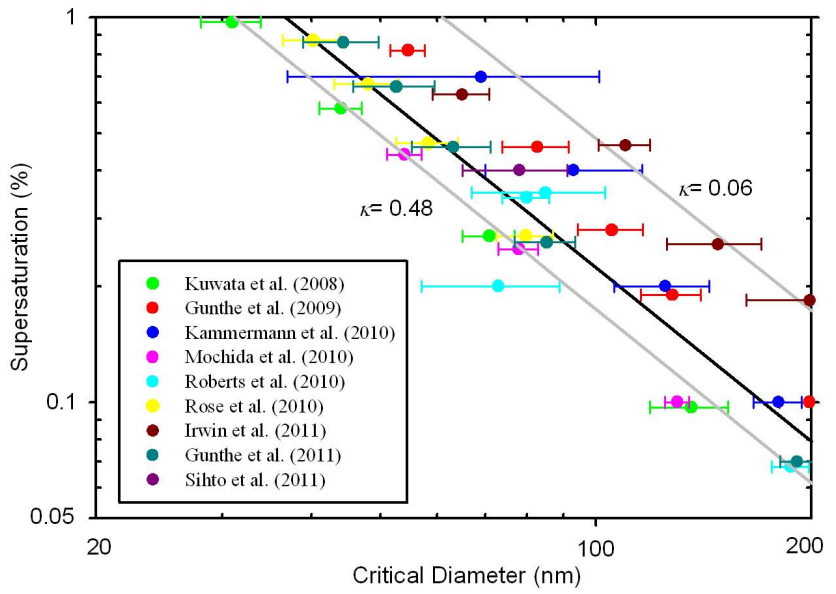

Fig. 1. The relationship between the particle dry size and the critical supersaturation. The calculations were done for the temperature of $298.15 \mathrm{~K}$ and under assumption that the droplet surface tension is that of water, i.e. $0.072 \mathrm{~N} \mathrm{~m}^{-1}$. The scale of the $y$-axis corresponds to maximum supersaturations reported for various cloud types in Table 17.3 of Seinfeld and Pandis (2006). The calculations are done for $\kappa$ values of 0.27 (black line) and for 0.48 and 0.06 (grey lines) which correspond to the simulated global mean of $\kappa=0.27 \pm 0.21$ (Pringle et al., 2010). Also, results from several field studies are displayed in symbols (see legend). The horizontal bars indicate reported standard deviations. For the study of Irwin et al. (2011), the results from terrestrial periods are presented (see Table 1 of the publication). Also, Irwin et al. (2011) reported standard deviations for the critical supersaturations, and these were converted to the corresponding critical diameters using Eq. (2).

of the droplet diameter $d$ and finding the maximum of the resulting curve. Conversely, for a given water supersaturation ratio, Eq. (1) can be solved iteratively to find the corresponding diameter $d_{\mathrm{c}}$, i.e. the minimum dry diameter needed for activation (threshold diameter). When the solute volume can be neglected at the stage of activation, Eq. (1) simplifies to the following form (Rissler et al., 2010):

$\ln \left(S_{\mathrm{c}}\right)=\sqrt{\frac{4 A^{3}}{27}} d_{\mathrm{dry}}^{-3 / 2} \kappa^{-1 / 2}$

The value of the threshold diameter can be found using Eq. (2) by solving the equation with respect to $d_{\text {dry }}$.

Figure 1 illustrates how the threshold diameter depends on the water vapor supersaturation and particle hygroscopicity for an atmospherically relevant parameter range. The calculations were performed using Eq. (1), and the $\kappa$ values were chosen according to the study of Pringle et al. (2010), who simulated global distributions of $\kappa$ values with a largescale climate model and reported a global mean value of $0.27 \pm 0.21$ for continental regions. As can be seen from Fig. 1, the particles need to have a size of a few tens of nanometers at the very least before they can act as $\mathrm{CCN}$ under atmospheric conditions. The threshold diameter depends strongly on the water vapor supersaturation, such that the slopes of the curves displayed in Fig. 1 are equal to $-3 / 2$. Variations in the particle hygroscopicity are also reflected in the threshold diameter: $d_{\mathrm{c}}$ varies by more than a factor of two between the two extreme values of $\kappa$. Despite such large variability, it can be argued that the size is relatively more important in CCN activation on the basis of Eq. (2) as $S_{\mathrm{c}}$ is more sensitive to $d_{\text {dry }}$ than to $\kappa$.

In addition to the hygroscopic properties of particles described by the parameter $\kappa$ in Eq. (1), there are other chemical effects that might affect $\mathrm{CCN}$ activation. These include droplet surface tension reduction caused by various surfactants (Facchini et al., 1999), associated surface-to-bulk partitioning of surface-active material (Sorjamaa et al., 2004; Prisle et al., 2010), and increases in the amount of the soluble material in humid aerosol particles prior to their activation due to the presence of slightly-soluble compounds in "dry" aerosol particles (Shulman et al., 1996; AbdulRazzak and Ghan, 2005), or due to the net transfer of semivolatile, water-soluble compounds from the gas phase to humid aerosol particles (Kulmala et al., 1993; Topping and McFiggans, 2012). The net effect of these processes is to reduce the value of $d_{\mathrm{c}}$ from values obtained directly from Eq. (2). Insoluble particles, such as fresh dust particles, can be activated into cloud droplets via water adsorption (Sorjamaa and Laaksonen, 2007; Kumar et al., 2011), in which case the relation between $S_{\mathrm{c}}$ and $d_{\mathrm{c}}$ is very different from that given by Eq. (2).

\subsubsection{Experimental findings}

Several experimental studies have reported "effective" threshold diameters, $d_{\mathrm{c}, \text { eff }}$, for atmospheric particle populations measured under various tropospheric conditions (Dusek et al., 2006; Hudson et al., 2007; Furutani et al., 2008; Kuwata et al., 2008; Quinn et al., 2008; Gunthe et al., 2009; Kammermann et al., 2010; Mochida et al., 2010; Roberts et al., 2010; Deng et al., 2011; Gunthe et al., 2011; Irwin et al., 2011; Kim et al., 2011; Sihto et al., 2011). The diameters $d_{\mathrm{c} \text {, eff }}$ are inferred typically from size-resolved activation efficiencies or from concurrent $\mathrm{CCN}$ and particle size distribution measurements (e.g. Furutani et al., 2008; Rose et al., 2010). In the first type of experiments, CCN and total number concentrations are measured concurrently for a certain set of dry diameters. This yields the fraction of $\mathrm{CCN}$ active particles as a function of the size, and $d_{\mathrm{c} \text {, eff }}$ can be determined from the data by estimating the diameter corresponding to the $50 \%$ activation efficiency. It is worth noting that $d_{\mathrm{c}, \text { eff }}$ obtained in this way is not a minimum diameter needed for activation because the activated fraction tends to increase gradually with increasing dry diameter so that a sigmoid function, rather than the step function, gives usually a good fit to the data (Rose et al., 2010). In the second type of experiments, $d_{\mathrm{c}, \text { eff }}$ is defined through a following type of 
relation:

$$
\frac{\int_{d_{c, \text { eff }}}^{d_{\max }} n\left(d_{\mathrm{p}}\right) d d_{\mathrm{p}}}{\mathrm{CN}_{\mathrm{tot}}}=\mathrm{AF}_{\text {tot }}
$$

Here $d_{\max }$ is the largest diameter measured with the particle sizing instrument, $n\left(d_{\mathrm{p}}\right)$ is the size distribution function, $\mathrm{CN}_{\text {tot }}$ is the total particle concentration (obtained by integrating $n\left(d_{\mathrm{p}}\right)$ over the particle size range), and $\mathrm{AF}_{\text {tot }}$ is the fraction of the particles that act as $\mathrm{CCN}$ (determined from the $\mathrm{CCN}$ measurements). One underlying assumption behind the approach is that particles are internally mixed even though this is rarely the case in the atmosphere (Furutani et al., 2008).

It should be emphasized that $d_{\mathrm{c}}$ and $d_{\mathrm{c} \text {, eff }}$ are not directly comparable with each other. This is because $d_{\mathrm{c}}$ is a theoretically-predicted size needed for a particle with a given chemical composition to activate, whereas $d_{\mathrm{c}, \text { eff }}$ is an estimate of the threshold activation diameter for an ambient particle population. In particular, the chemical composition of atmospheric particles tend to vary even among particles having similar sizes, which alone makes direct comparison of $d_{\mathrm{c}}$ and $d_{\mathrm{c}, \text { eff }}$ problematic. Nevertheless, $d_{\mathrm{c}, \text { eff gives an useful }}$ measure for the diameter required for $\mathrm{CCN}$ activation in the atmosphere, and results from several studies referred above are displayed in Fig. 1 for illustration. The data points are seen to scatter around the predicted global mean value of $\kappa=0.27$ and fall generally within a standard deviation of the global $\kappa$ distribution. It is also seen that $d_{\mathrm{c} \text {, eff may vary }}$ quite notably between different measurements conducted at similar supersaturation levels. A plausible explanation is that these differences reflect the variability in the particle chemical composition.

The threshold diameter for a particle population depends not only on the aerosol composition and mixing state, but also on the maximum supersaturation reached in clouds. This quantity, in turn, is a function of the aerosol loading and meteorological conditions (McFiggans et al., 2006; Reutter et al., 2009; Ghan et al., 2011). Excluding pristine air masses and clouds formed as a result of a strong convective activity, maximum cloud supersaturations are expected to lie mostly below 0.3\% (Seinfeld and Pandis, 2006: Hegg et al., 2009 and references therein; Hudson et al., 2010). By combining this information with the observed values of $\kappa$ between about 0.1 and 0.45 for sub- $100 \mathrm{~nm}$ particles originating from nucleation (e.g. Dusek et al., 2010; Cerully et al., 2011; Sihto et al., 2011; Levin et al., 2012), we end up with threshold diameters larger than about $70-80 \mathrm{~nm}$ in boundary-layer clouds (Fig. 1). Other chemical effects discussed in Sect. 2.1.1 likely decrease the minimum threshold diameter for CCN activation further. The minimum "dry" sizes of particles observed to participate in droplet formation in real atmospheric clouds are usually in the range $50-150 \mathrm{~nm}$ (Henning et al., 2002, and references therein; Komppula et al., 2005; Anttila et al., 2009).

\subsection{Nuclei growth to $\mathrm{CCN}$ sizes}

The $\kappa$-Koehler calculations and other findings presented in the previous section imply that nucleated particles need to grow to sizes between about 50 and $100 \mathrm{~nm}$ to act as CCN in boundary-layer clouds. The initial size of freshly-nucleated particles, on the other hand, is about 1-2 nm (e.g. Kulmala et al., 2007). This means that nucleated particles need to undergo significant growth before they can contribute to atmospheric CCN populations.

Based on particle number size distribution measurements, nuclei growth rates have been determined in a large number of lower-troposphere environments (Kulmala et al., 2004a; Kulmala and Kerminen, 2008, and references therein). The vast majority of the reported growth rates lie in the range 1$10 \mathrm{~nm} \mathrm{~h}^{-1}$. Lower values have occasionally been observed in remote continental sites and, more recently, also in the marine boundary layer (O'Dowd et al., 2010). Growth rates in excess of $10 \mathrm{~nm} \mathrm{~h}^{-1}$ have been reported in a few polluted environments, as well as in plumes from intense and localized sources of aerosol precursor vapors. We may conclude that the growth of nucleated particle to $\mathrm{CCN}$ sizes takes from a few hours up to about three days in the lower troposphere, with longer growth times more typical for remote locations.

The likelihood that nucleated particles will grow to $\mathrm{CCN}$ sizes, called also the $\mathrm{CCN}$ formation efficiency, depends on the competition between the rates of growth and removal processes (Kerminen et al., 2004; Pierce and Adams, 2007). At the initial stages of their growth, the removal of nuclei is dictated by their coagulation with larger pre-exiting particles and, in case the nuclei number concentration is extremely high, also by their self-coagulation (Leppä et al., 2011). McMurry et al. (2005) and Kuang et al. (2010) investigated theoretically the competition between the nuclei growth and their scavenging by coagulation. They showed that nucleation is unable to initiate detectable aerosol formation unless the very initial nuclei growth rate exceeds a certain value dictated by the pre-existing aerosol loading. Kerminen and Kulmala (2002) derived a simple analytical formula by which the scavenging of growing nuclei by coagulation can be taken into account in large-scale models or in analyzing field measurements. An updated version of this formula was introduced later by Lehtinen et al. (2007). Anttila et al. (2010) extended it further to take into account nuclei self-coagulation. When nuclei grow further, their scavenging by coagulation slows rapidly down and other removal processes may become important. These include the dilution of the air mass where nucleation had occurred and, at time scales longer than a few hours, the scavenging of growing nuclei by rain. Pierce and Adams (2007) developed a general modeling framework by which the $\mathrm{CCN}$ formation efficiency of nucleated particles can be estimated. They predicted a large variability for 


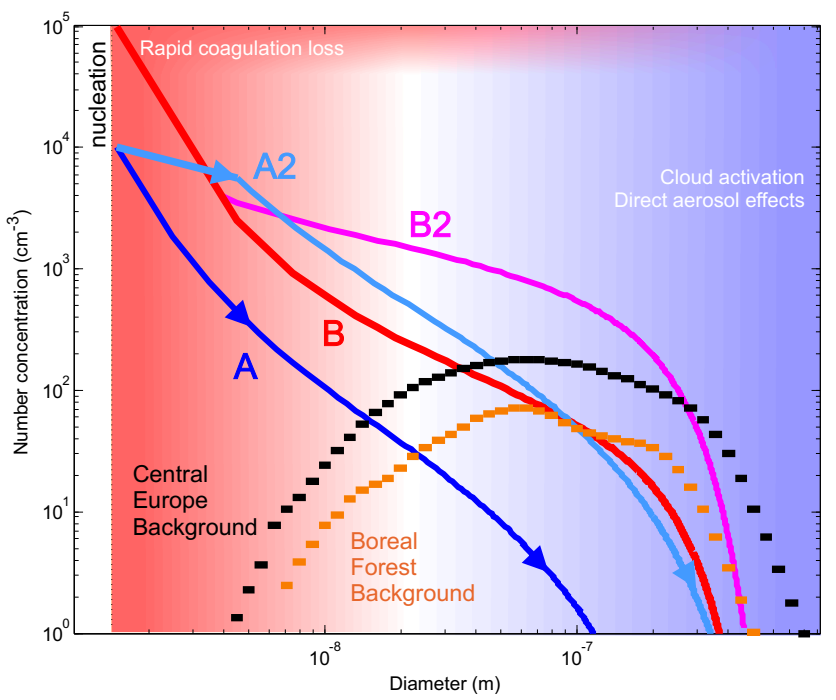

Fig. 2. Analysis of loss/growth processes affecting the NPF-CCN relationship using trajectories of newly-formed particles in the diameter-concentration axis. Different initial particle number concentrations will produce widely different concentrations in the $\mathrm{CCN}$ size range, depending on the background aerosol concentrations (given here as annual median in two environments according to Asmi et al. (2011b) and depicted as dotted lines) and condensation growth rates (comparable to the mean values reported by Yli-Juuti et al., 2011). A nucleation event taking place in a relatively clean region will have little influence on $\mathrm{CCN}$ concentrations when nucleated particles are growing slowly in size $\left(1 \mathrm{~nm} \mathrm{~h}^{-1}\right.$, trajectory A). If, however, nucleation is accompanied by a higher particle growth rate in the first 1.5 hours $\left(5 \mathrm{~nm} \mathrm{~h}^{-1}\right.$, trajectory A2), concentrations in the $\mathrm{CCN}$ size range are considerable. A strong nucleation event in a polluted region has a low $\mathrm{CCN}$ production efficiency due to losses (trajectory B). If, however, concentrations of pre-existing larger particles decrease after a few hours (e.g. precipitation or mixing event, trajectory B2), $\mathrm{CCN}$ resulting from atmospheric nucleation become much more important.

nuclei CCN formation efficiencies between different atmospheric environments. Kuang et al. (2009) applied a slightly modified version of this approach for a field measurement campaign, and found the $\mathrm{CCN}$ formation efficiencies to be in a relatively narrow range of $1-20 \%$.

In view of the above, the $\mathrm{CCN}$ formation efficiency of nucleation depends on (1) the initial (sub-3 to $10 \mathrm{~nm}$ ) nuclei growth rate, which dictates whether nucleation can initiate detectable aerosol formation and how big fraction of freshlynucleated particles survive from coagulation with larger particles, and (2) the average nuclei growth rate, which determines whether growing nuclei reach CCN sizes before being scavenged by dry or wet deposition. The interaction between the nuclei growth and loss rates is schematically shown in Fig. 2. The overall CCN formation efficiency is at least as much controlled by the particle growth/loss dynamics as it is by the initial nucleation rate.
Large uncertainties regarding the growth rate of the smallest nuclei still exist, since this quantity depends in a complicated way on the dynamics and thermodynamics of the condensation process, and possibly also on other growth processes (Anttila et al., 2004; Kulmala et al., 2004b; Nieminen et al., 2010). While in theory these processes could either enhance or suppress the growth of very small nuclei, the few existing field measurements suggest that the sub- $3 \mathrm{~nm}$ nuclei usually grow somewhat slower than larger nuclei (Hirsikko et al., 2005; Manninen et al., 2010; Kuang et al., 2012).

From a modeling point of view it is critical to know which vapors drive the growth of freshly-formed clusters to $\mathrm{CCN}$ sizes, and how this growth depends on the environment, atmospheric conditions and particle size. While the exact identities of the condensing vapors and vapor-uptake mechanisms are not fully known, there is a growing number of observational studies directing the development of modeling approach for ultrafine particle growth. Sulfuric acid, together with water and basic compounds such as ammonia and amines, appear to drive the initial steps of atmospheric particle formation in many environments (Sipilä et al., 2010; Berndt et al., 2010; Kirkby et al., 2011; Zhang et al., 2012). Excluding some sulfur-rich conditions (Jung et al., 2006; Zhang et al., 2009), atmospheric sulfuric acid concentrations are, however, too low to fully explain the growth of the new particles to CCN sizes (Kuang et al., 2010; Riipinen et al., 2011; Pierce et al., 2011; Riccobono et al., 2012). Kulmala et al. (1998) and Kerminen et al. (2000) suggested that lowvolatile organic compounds would be responsible for the majority of the particle growth. The important role of organic compounds in growing nucleated particle to $\mathrm{CCN}$ sizes has later been confirmed in many environments (e.g. Tunved et al., 2006; Spracklen et al., 2008b; Laaksonen et al., 2008; Smith et al., 2010).

The number of atmospherically relevant organic compounds is very large, and the properties of these molecules are not well known (e.g. Goldstein and Galbally, 2007, Hallquist et al., 2009). This complicates the representation of organic condensation onto freshly-formed particles, and it is likely that no single organic vapor or precursor dominates the growth of nucleated particles to CCN sizes. Model predictions of nucleation mode particle growth are very sensitive to the volatility of organic vapors, as well as to the approach with which organic vapors are converted into aerosol loadings and size distributions (Riipinen et al., 2011). The treatment of condensable organics in the current state-of-theart atmospheric models is essentially two-fold: some models assume that the condensable organics are completely non-volatile (e.g. Spracklen et al., 2008b; Makkonen et al., 2009), while others account for the volatility but assume that the aerosol is in constant thermodynamic equilibrium with the gas phase (e.g. Pye and Seinfeld, 2010). Neither of these approaches adequately describes atmospheric aerosol populations, since the former neglects evaporation of organic aerosol and the latter cannot capture the growth of 
freshly-formed particles. To improve the estimates of the climate impacts of organics, atmospheric models need approaches that capture nanoparticle growth without compromising the predictions of total aerosol mass budgets and properties. First attempts toward this approach have been presented, typically combining a semi-volatile species that can evaporate and a low-volatility species that condenses with a negligible saturation vapor pressure (Yu, 2011; Riipinen et al., 2011).

\section{Observations of atmospheric $\mathrm{CCN}$ production}

\subsection{Overview of existing observations}

While the direct measurement of atmospheric nucleation remains a big challenge (Kulmala et al., 2007, 2012), observation of the subsequent growth of nucleated particles to larger sizes is possible for so-called regional nucleation events (e.g. Kulmala and Kerminen, 2008). In such events, nucleation and growth occur simultaneously and relatively homogeneously over large spatial scales, making it possible to monitor the time evolution of a growing particle population at a fixed measurement site. During the last decade or so, regional nucleation events producing particles of several tens of $\mathrm{nm}$ in diameter have been found to be frequent in a large variety of lower-troposphere environments, including forested areas, many other remote continental regions, urban areas, and heavily-polluted environments (see Kulmala and Kerminen, 2008, and references therein). Similar events have also been observed in several high-altitude sites in the mountains (Shaw, 2007; Venzac et al., 2008, 2009; Kivekäs et al., 2009; Boulon et al., 2010), whereas in the marine boundary layer they appear to be rare (Heintzenberg et al., 2004; O'Dowd et al., 2010).

Regional nucleation events are clear indicators of atmospheric CCN production initiated by nucleation, yet only few experimental studies have attempted to quantify the strength of this source. Lihavainen et al. (2003) and later Asmi et al. (2011a) analysed a large number of nucleation events measured at a remote site in Northern Finland, and found that number concentrations of 50,80 and $100 \mathrm{~nm}$ particles were enhanced, on average, by the factors of 2.6, 1.7 and 1.5, respectively, from the beginning of a nucleation event to the end of the event. Slightly smaller CCN enhancement factors were reported by Sihto et al. (2011) for the SMEAR II station in Southern Finland. By relying on continuous data from three measurement stations, Tunved et al. (2006) estimated that nucleation is the dominant source of the aerosol number concentration and a significant contributor to $\mathrm{CCN}$ concentrations over the whole Scandinavian boreal forest region during the summer part of the year. Laaksonen et al. (2005) found that nucleation significantly enhances the concentrations of CCN-size particles at a highly-polluted region of Po Valley, Italy, despite strong primary particle emissions there.
Yue et al. (2011) reported average CCN enhancement factors between about 1.5 and 2.5 in Beijing, China, with larger values corresponding to nucleation events with higher particle growth rates. Kuang et al. (2009) derived an overallaverage $\mathrm{CCN}$ enhancement factor of 3.8 for nucleation events recorded at three different continental sites, of which two (Boulder, CO and Atlanta, GA) were located in the USA and one in Mexico (Tecamac).

Hamed et al. (2010) investigated how past reductions in $\mathrm{SO}_{2}$ emissions might have affected secondary $\mathrm{CCN}$ production by comparing long-term measurements in a central European location between two time periods (1996-1997 vs. 2003-2006). They found that, consistent with substantial European-scale $\mathrm{SO}_{2}$ emission reductions over this time, both the frequency of nucleation events and the magnitude of new particle formation during the events decreased considerably. On the contrary, CCN production associated with atmospheric nucleation was found to increase over the same time period, most likely as a result of increased nuclei growth rates caused by increasing biogenic aerosol precursor emissions. The study by Hamed et al. (2010) points out the complicated interplay between natural and anthropogenic emission and atmospheric $\mathrm{CCN}$ production.

Only few investigators have linked nucleation measurements directly to corresponding $\mathrm{CCN}$ or cloud droplet number concentration measurements. Kuwata et al. (2008) measured aerosol number size distributions and $\mathrm{CCN}$ concentrations at four supersaturations at Jeju Island, Korea. They reported a few events where nucleation was followed by clear increases in $\mathrm{CCN}$ number concentrations after a few hours from the beginning of the event. Similar observations were made by Creamean et al. (2011) at a remote rural mountain site in California, USA, by Levin et al. (2012) at a forested site in Colorado, USA, and by Pierce et al. (2012) in a forested mountain valley in western Canada. Wiedensohler et al. (2009) and Yue et al. (2011) found rapid growth of nucleated particles to $\mathrm{CCN}$ in a highly-polluted region in Beijing, China, and high CCN concentrations resulting from nucleation. Sihto et al. (2011) analyzed a full year of simultaneous aerosol number size distribution and CCN concentration measurements at a forested site (SMEAR II station in Hyytiälä) in Southern Finland. They found that nucleation enhanced $\mathrm{CCN}$ number concentration by 70 to $110 \%$, depending on the supersaturation level. Usually, CCN concentrations at highest supersaturations increased after a few hours from the beginning of the nucleation event, whereas CCN concentrations measured at low supersaturations tended to reach their maximum during the following night or next day (Sihto et al., 2011). Kerminen et al. (2005) observed that nucleated particles not only grew to $\mathrm{CCN}$ sizes, but also participated in cloud droplet formation at a remote continental site in Northern Finland.

In addition to regional nucleation events, production of new $\mathrm{CCN}$ has been reported in association with more localized sources. These include power plant plumes (e.g. Brock 
et al., 2002), and some coastal areas where very intense nucleation bursts followed by rapid growth of nucleated particles to larger sizes have been observed to take place (O'Dowd and de Leeuw, 2007; Whitehead et al., 2010). Convection and related cloud outflow regions in the free troposphere have been identified as active regions for nucleation (Twohy et al., 2002; Hermann et al., 2003; Benson et al., 2008), as was also the upper troposphere (e.g. Clarke, 1993; Singh et al., 2002; Hermann et al., 2003). Due to the lack of continuous measurements, however, practically no experimental evidence on associated $\mathrm{CCN}$ production in these regions has been obtained so far.

In view of the above, $\mathrm{CCN}$ production due to atmospheric nucleation appears to be a common phenomenon. Unfortunately, existing observations are too limited for drawing any quantitative estimates on how significant this process might be for the tropospheric $\mathrm{CCN}$ budget. In order to improve this situation, and to provide data for models simulating atmospheric CCN formation, more analyses on long-term measurements in different environments are needed. The analyses should involve particle number size distribution measurements at minimum, preferably including parallel CCN measurements. In the following sub-section we will present new experimental data related to this issue.

\subsection{Examples of recent long-term observations}

In order to provide insight into how atmospheric nucleation affects $\mathrm{CCN}$ concentrations over a full annual cycle, and to illustrate the challenges in quantifying the contribution of nucleation events to the CCN budget, we analyzed four long-term measurement datasets obtained from sites in Hyytiälä, Pallas, Vavihill and Botsalano. The station in Hyytiälä $\left(61^{\circ} 50^{\prime} \mathrm{N}, 24^{\circ} 17^{\prime} \mathrm{E}, 181 \mathrm{~m}\right.$ a.s.l) is located inside a boreal forest zone in Finland and represents typical regional background conditions for higher latitudes of Europe (Hari and Kulmala, 2005). The Pallas station $\left(67^{\circ} 58^{\prime} \mathrm{N}\right.$, $24^{\circ} 07^{\prime} \mathrm{E}, 560 \mathrm{~m}$ a.s.l) is a remote continental site at the northern edge of the boreal forest zone in Finland (Hatakka et al., 2003). The Vavihill station $\left(56^{\circ} 01^{\prime} \mathrm{N}, 13^{\circ} 09^{\prime} \mathrm{E}, 172 \mathrm{~m}\right.$ a.s.l) is located in the southernmost part of Sweden and represents continental background conditions (Kristensson et al., 2008). The site in Botsalano, South-Africa $\left(25^{\circ} 32^{\prime} \mathrm{S}\right.$, $25^{\circ} 45^{\prime} \mathrm{E}, 1424 \mathrm{~m}$ a.s.l), is located in dry savannah environment and can be considered as a continental background site (Laakso et al., 2008).

At all sites, CCN number concentrations were derived from particle number size distributions measured with a differential mobility particle sizer (DMPS). In addition to the DMPS data, CCN number concentrations at fixed supersaturations were measured in Hyytiälä and Vavihill using a cloud condensation nuclei counter (CCNC) over limited time periods. For detailed descriptions of the measurements systems at each location, we refer to Hari and Kulmala (2005), Kris- tensson et al. (2008), Laakso et al. (2008), Lihavainen et al. (2008), Fors et al. (2011) and Sihto et al. (2011).

In the analyses summarized in Table 1, we considered only such nucleation events for which the particle formation and growth rates could be determined with a good confidence level (Type I events; see Dal Maso et al., 2005). Strict selection criteria were then further applied to determine the most representative and usable events. Days with clear pollution peaks and episodes, as well as days with persistent polluted air (high accumulation mode concentrations) were disregarded due to their possible effects on $\mathrm{CCN}$ concentrations. In several instances, a late dilution of the boundary layer and/or change of air mass resulted in higher $\mathrm{CCN}$ concentrations prior to the nucleation event - these events were also not used in the analysis. Moreover, we considered only those nucleation events where particles grew to at least $50 \mathrm{~nm}$ in diameter. The selection was carried out manually by visually examining each event.

As mentioned previously, supersaturation within the cloud has a direct effect on the critical diameter $d_{\mathrm{c}}$, and, therefore, defining the size range of particles that constitute the $\mathrm{CCN}$ concentration is important. In order to account for the variability of ambient in-cloud supersaturation, four thresholds defining the lower limit of CCN concentration were used: $50 \mathrm{~nm}, 80 \mathrm{~nm}, 100 \mathrm{~nm}$ and $150 \mathrm{~nm}$ of the dry particle size. Hereafter, these will be denoted as $N_{50}, N_{80}, N_{100}$ and $N_{150}$, respectively. The contribution of any given nucleation event to the CCN concentration was studied on the basis of comparison of the $\mathrm{CCN}$ concentration $N_{\mathrm{CCN} \text { prior }}$ prior to and the maximum $\mathrm{CCN}$ concentration $N_{\mathrm{CCNmax}}$ during an event. The $N_{\mathrm{CCNmax}}$ was chosen as the most straightforward parameter, which, while may not be the best representation of $\mathrm{CCN}$ concentration after the event, gives a rough estimate of the observed maximum number of particles, both new and preexisting, that are present in the atmosphere during an event. Another reason for selecting $N_{\mathrm{CCNmax}}$ is the difficulty in defining the end of a nucleation event. $N_{\mathrm{CCNprior}}$ was calculated as a one-hour average concentration immediately prior to the appearance of the newly formed nucleation mode particles, whereas $N_{\mathrm{CCNmax}}$ was calculated as a maximum onehour average concentration during an event. The contribution of the nucleation to $\mathrm{CCN}$ concentrations during the days fulfilling the above criteria was then examined in both relative and absolute terms.

\subsubsection{Connection between $\mathrm{CCN}$ derived from DMPS and $\mathrm{CCNC}$ measurements}

Figures 3 and 4 illustrate an example of a nucleation event in Hyytiälä and Vahivill, respectively, connecting DMPS and Cloud Condensation Nuclei Counter (CCNC) measurements. The event in Fig. 3 is a typical spring type I event in Hyytiälä, with the new particle formation starting at 05:30 UTC and the growth continuing until 16:00 UTC. It is visible that $N_{50}$ and $N_{100}$ reached their maximum values 8 and $10.5 \mathrm{~h}$ after 
Table 1. Statistical details of the analyzed data. For each station, $N$ denotes the total number of observed Type I nucleation event days during the period considered here, $F$ gives the corresponding frequency of such days, $N_{\text {an }}$ denotes the total number of Type I nucleation event days selected for the analyses depicted in Figs. 5 and 6, and $P_{\text {an }}$ is the percentage of the Type I nucleation event days used in our analyses.

\begin{tabular}{lllll}
\hline Station & Hyytiälä & Pallas & Botsalano & Vavihill \\
\hline Period & Feb 1996-Oct 2009 & Apr 2000-Dec 2010 & Jul 2006-Feb 2008 & Jan 2008-Dec 2010 \\
$N$ & 593 & 68 & 183 & 290 \\
$F$ & $11.8 \%$ & $2.0 \%$ & $29.4 \%$ & $8.8 \%$ \\
$N_{\text {an }}$ & 257 & 47 & 54 & 79 \\
$P_{\text {an }}$ & $43.3 \%$ & $69.1 \%$ & $29.5 \%$ & $27.2 \%$ \\
\hline
\end{tabular}

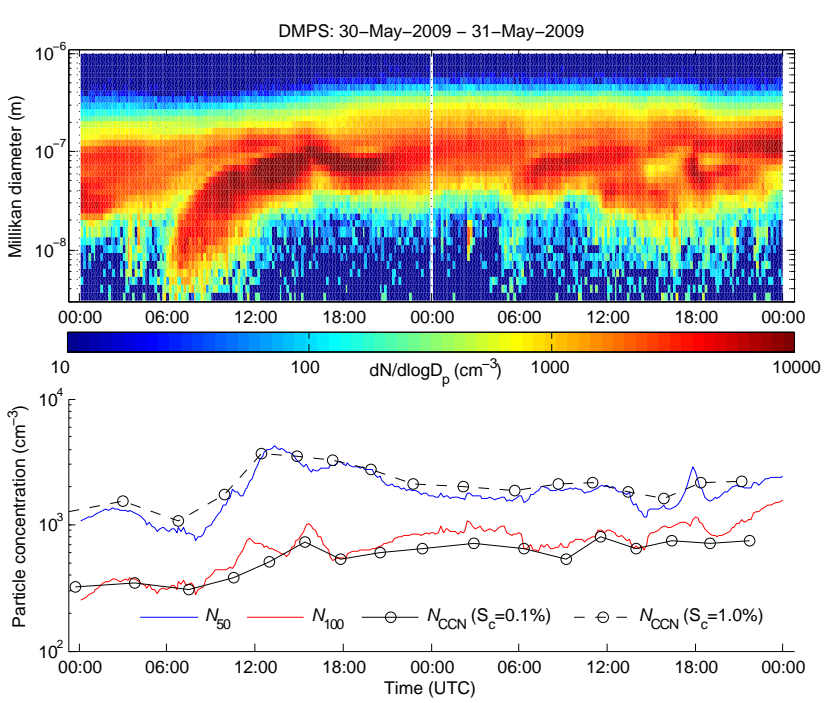

Fig. 3. An example of a nucleation event in Hyytiälä station on May 30, 2009. The top panel depicts the time series of particle number size distribution. The bottom panel shows the corresponding time series of two DMPS-derived CCN concentrations $\left(N_{50}\right.$ and $\left.N_{100}\right)$ and two CCN concentrations $N_{\mathrm{CCN}}$ measured by the CCNC at two supersaturation $\left(\mathrm{S}_{\mathrm{c}}\right)$ levels of $0.1 \%$ and $1.0 \%$.

the beginning of the event, respectively, and represent an increase of $317 \%$ and $202 \%$ in corresponding CCN concentrations compared with before the start of the events. Similarly, the event in Fig. 4 is an autumn type I event in Vavihill, with the new particle formation starting at 10:40 UTC and the growth continuing until the early morning hours of the next day. The values of $N_{50}$ and $N_{100}$ reached their maximum 8 and 11 hours after the beginning of the event, respectively, and represent an increase of $238 \%$ and $86 \%$ in corresponding CCN concentrations compared with before the start of events.

Figures 3 and 4 demonstrate that $\mathrm{CCN}$ concentrations calculated from the DMPS measurements correspond very well with those measured by the CCNC at two different supersaturation $\left(S_{\mathrm{c}}\right)$ levels. Indeed, the peaks in $N_{50}$ and $N_{100}$ occur at approximately at the same time as peaks in $N_{\mathrm{CCN}}$ for $S_{\mathrm{c}}$ of $1.0 \%$ and $0.1 \%$, respectively. In both example cases, $N_{50}$ represents the $\mathrm{CCN}$ concentration accurately for $S_{\mathrm{c}}$ slightly

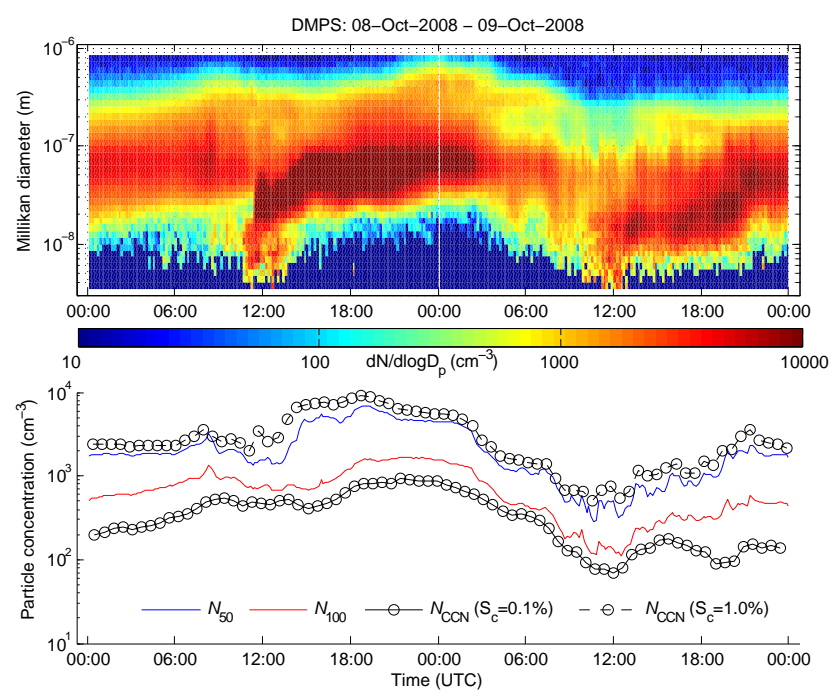

Fig. 4. An example of a nucleation event in Vavihill station on October 8. 2008. The top panel depicts the time series of particle number size distribution. The bottom panel shows the corresponding time series of two DMPS-derived CCN concentrations $\left(N_{50}\right.$ and $\left.N_{100}\right)$ and two $\mathrm{CCN}$ concentrations $N_{\mathrm{CCN}}$ measured by the $\mathrm{CCNC}$ at two supersaturation $\left(S_{\mathrm{c}}\right)$ levels of $0.1 \%$ and $1.0 \%$.

below $1.0 \%$, and $N_{100}$ represents the CCN concentration accurately for $S_{\mathrm{c}}$ slightly above $0.1 \%$. Both these events occurred in air mass with relatively high and persistent particle number concentrations in the accumulation mode. As a result, CCN measured prior, during and after the event included both nucleated and primary aerosol particles.

\subsubsection{Increases of $\mathrm{CCN}$ concentrations during nucleation events}

Figure 5 shows relative increases in CCN number concentrations during the selected subset of nucleation event days at the four stations. As expected, nucleation events had a noticeable effect on CCN concentrations in all seasons and locations considered here. The highest relative increase in $\mathrm{CCN}$ concentrations was observed in Pallas, with an average increase in the value of $N_{50}$ of about $360 \%$. This feature is a direct result of very low absolute particle 


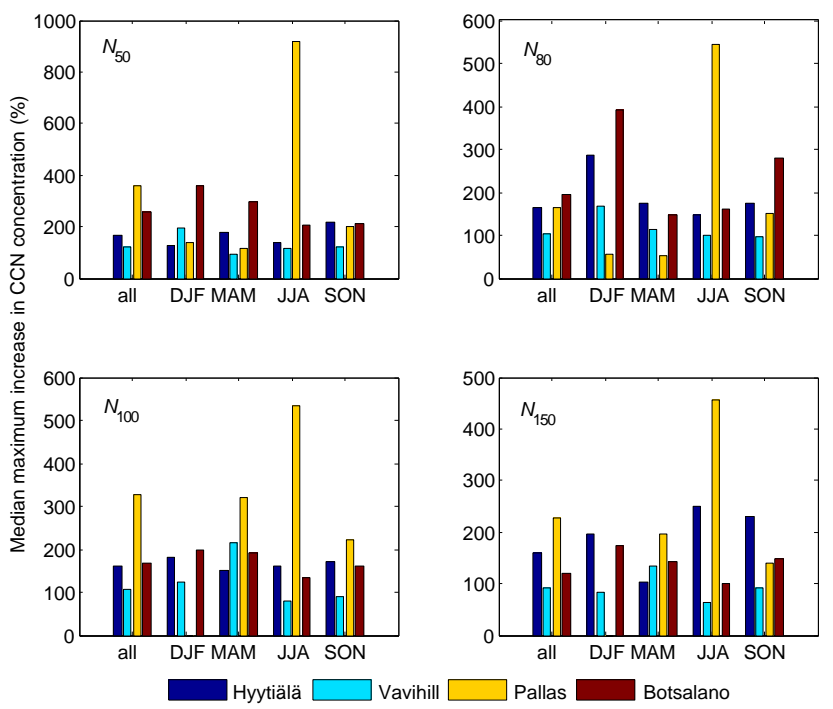

Fig. 5. Median maximum increase in four examined CCN concentrations expressed in percent as a result of nucleation at four locations. The results are shown separately for all events and for different seasons.

number concentrations at this remote background boreal station compared with the three other sites (Dal Maso et al., 2007; Kristensson et al., 2008; Laakso et al., 2008; Asmi et al., 2011a). On an annual basis, the relative increases in $\mathrm{CCN}$ concentrations were highest during the summertime in both Pallas and Botsalano. In Pallas, this is probably due to the highest particle growth rates at this time of the year (Asmi et al., 2011a). In Botsalano, the local summer (December, January and February) is a wet season with frequent nucleation events, precipitation episodes, high relative humidity and low concentrations of atmospheric pollutants (Laakso et al., 2008). A more recent study by Laakso et al. (2012) reported that the observed highest increase during local summer may be attributed to higher growth rates stemming from higher biogenic emissions, as well as to generally cleaner air masses resulting from a weakened anticyclonic circulation, frequent rainfall and a smaller condensation sink. Over the course of the whole year, the smallest relative increase for all four CCN concentrations was observed in Vavihill, for almost all seasons and CCN concentrations the relative increase being always smaller than in Hyytiälä. This might be due to higher background aerosol concentrations in Vavihill due to its closer proximity to central Europe, regional conurbations and intense ship traffic lines in the waters surrounding southern Sweden. No seasonal pattern in the relative increase in $\mathrm{CCN}$ concentrations as a result of nucleation events were observed in Hyytiälä and Vavihill, although in the latter the smallest relative increase was observed during the summer months.

Figure 6 shows the absolute increases in $\mathrm{CCN}$ number concentrations at the four stations. With the exception of $N_{100}$ in

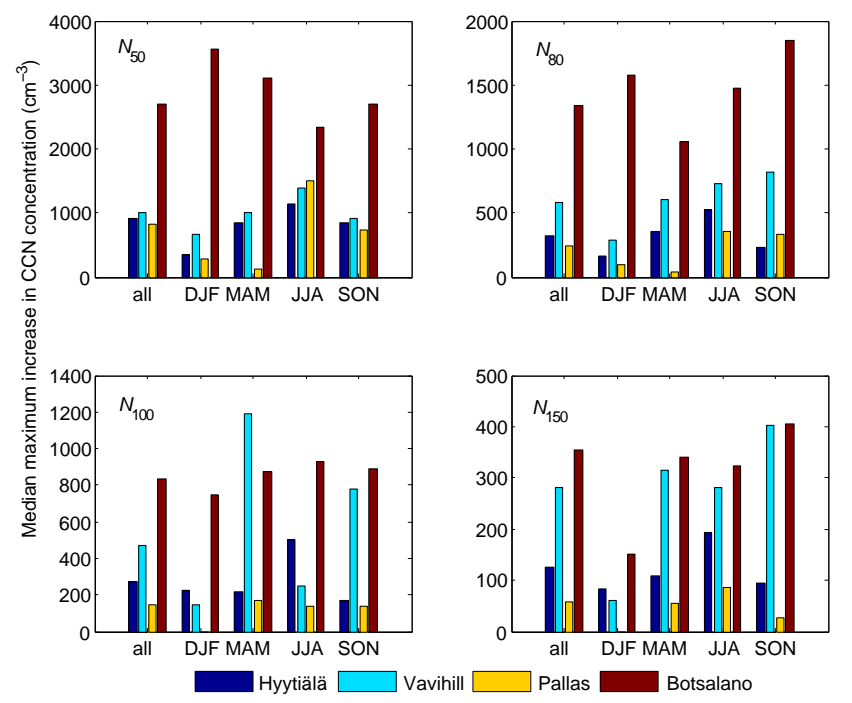

Fig. 6. Median maximum increase in four examined CCN concentrations expressed in particles per $\mathrm{cm}^{3}$ as a result of nucleation at four locations. The results are shown separately for all events and for different seasons.

Vavihill in the spring, for all $\mathrm{CCN}$ diameters and during all seasons, the absolute number of newly introduced CCN-size particles was highest in Botsalano. During the local summer $N_{50}$ can increase by as much as $\sim 3500$ particles $\mathrm{cm}^{-3}$ as a result of a nucleation event. Considering the fact that background aerosol concentrations in Botsalano are, on average, higher than in Hyytiälä, Vavihill and Pallas (Dal Maso et al., 2007; Laakso et al., 2008), the observed increases in CCN concentrations must be due to fairly intense nucleation events with high particle growth rates. Indeed, average growth rates of nucleated particles in Botsalano (Laakso et al., 2008; Vakkari et al., 2011) are considerably higher than those at the three other sites (Dal Maso et al., 2007; Kristensson et al., 2008; Asmi et al. 2011a). As a result, the average time it takes for particles to grow to $150 \mathrm{~nm}$ in diameter during a nucleation event is on the order of 10 hours in Botsalano, as compared with 20 hours or more in Hyytiälä, Vavihill and Pallas. The overall effect of nucleation events on the atmospheric CCN concentrations in Botsalano was large, but only when considering the absolute increase in CCN concentrations: high background number concentrations resulted in a smaller relative increase when compared to the other stations (Fig. 5). Vavihill showed fairly large absolute increases in CCN concentrations, especially for $N_{100}$ and $N_{150}$, indicating also the occurrences of intense nucleation events. For both Hyytiälä and Pallas the largest absolute increase in $\mathrm{CCN}$ concentrations was observed during the summer months, which is attributed to higher biogenic emissions and, hence, higher formation and growth rates. The same seems not to be case for Vavihill, where no annual trend in absolute increase was observed, with the exception of a minimum in the winter. 


\subsubsection{Discussion}

The examples presented above raise several important issues that need to be kept in mind in future analyses. To start with, when discussing the importance of atmospheric nucleation to $\mathrm{CCN}$ formation in different locations, it is important to distinguish between (i) the absolute increase in $\mathrm{CCN}$ concentrations associated with individual nucleation events, (ii) the corresponding relative increase, and (iii) the overall contribution of nucleation to the CCN budget. For example, the absolute and relative $\mathrm{CCN}$ increases depend in very different ways on primary aerosol particle number concentrations. When looking at the CCN budget, the frequency of nucleation events needs to be taken into account as well. This is not straightforward, and the contribution of nucleation to the overall CCN budget is likely to be sensitive to the subset of nucleation events taken into consideration (see Table 1 for differences in event frequencies and fraction of events used in our analysis). This form of analysis cannot easily quantify the fraction of the $\mathrm{CCN}$ that existed before nucleation started that were due to nucleation events in previous days in other locations. Additional challenges include the quantification of growth of additional particles created by nucleation to the $\mathrm{CCN}$ range during the days following nucleation, the lifetimes of these particles etc.

The approach applied here can be compared with two other ones applied recently. Asmi et al. (2011a) analyzed nucleation events in Pallas and investigated their contribution to the CCN budget $\left(N_{80}\right)$ by defining the end of an event and the time when nucleation mode particles reached the size defining the lower limit of CCN. Comparing our results for Pallas with those by Asmi et al. (2011a) revealed differences in both absolute and relative increases in $\mathrm{CCN}$ concentrations caused by nucleation, but similarities in the seasonal patterns of these increases. For $N_{80}$ the overall increases of $496 \%$ and $210 \%\left(358 \mathrm{~cm}^{-3}\right.$ and $\left.280 \mathrm{~cm}^{-3}\right)$ were found in this and the study by Asmi et al. (2011a), respectively. The apparent reason for these differences is the different method used to determine the contribution of nucleation to $\mathrm{CCN}$. Both studies agree, however, in that the largest contribution of nucleation to CCN budget in Pallas occurred in the summer. The method described by Laakso et al. (2012) for nucleation events in Botsalano was similar to the one used here, except that Laakso et al (2012) defined the end of each event and used the $\mathrm{CCN}$ concentration measured at that time instead of the maximum $\mathrm{CCN}$ concentration when calculating changes in $\mathrm{CCN}$ concentrations caused by nucleation. Our results for the Botsalano station agree quite well with those by Laakso et al. (2012), with the difference being the weaker seasonal variability of $\mathrm{CCN}$ increases in our analysis.

In order to consistently compare the three methods described earlier in this section, a subset of Type I nucleation events in Hyytiälä in 2002 was analyzed by using all the three methods. It quickly became apparent that such a comparison is a complicated task, since certain methods may not be

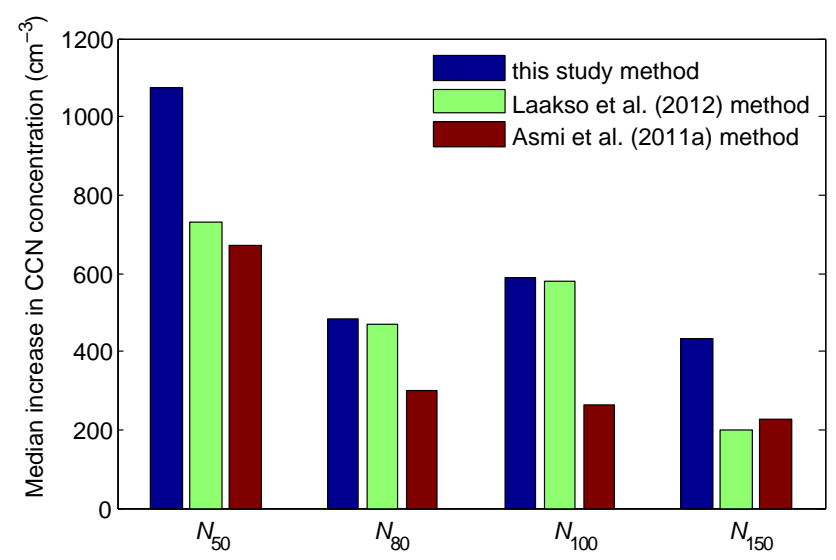

Fig. 7. Median increase in four examined CCN concentrations per $\mathrm{cm}^{3}$ as a result of nucleation, computed using the method presented in this paper and two other described methods. The Figure is based on a subset of nucleation events in Hyytiälä in 2002 for which all three methods produced reasonable results.

appropriate for a particular event (e.g., a higher $\mathrm{CCN}$ concentration prior to an event, leading to a negative increase in $\mathrm{CCN}$ concentration), while any other method may work well for the same event. Because of this, we analyzed only those events for which all the three methods produced physically reasonable results. The comparison revealed that the method used in this paper produced the highest increases in CCN number concentrations (Fig. 7), which is logical considering that the method utilized the maximum $\mathrm{CCN}$ concentration during an event. The method used by Asmi et al. (2011a) produced usually the smallest increases in CCN concentrations. When comparing the different threshold diameters defining the lower limit of the $\mathrm{CCN}$ concentration, no systematic pattern in estimated $\mathrm{CCN}$ increases between the methods by Asmi et al. (2011a) and Laakso et al. (2012) could be identified (Fig. 7).

The differences in the methods used by various investigators and, more importantly, the differences in results indicate a clear need for standardized procedures and robust algorithms when studying and quantifying the contribution of nucleation events to the atmospheric CCN concentrations based on measurement data. A big challenge in any approach used is to distinguish between primary particles and particles formed originally by atmospheric nucleation. In order to comprehensively investigate the atmospheric $\mathrm{CCN}$ budget and the contribution of nucleation events to it, the analysis should include not only the nucleation event days, but also non-events days and undefined days (Buenrostro Mazon et al., 2009). Supplementing the analysis with the model simulations would probably be beneficial, as demonstrated by Laakso et al. (2012). In summary, measurement data can provide a useful insight into the $\mathrm{CCN}$ concentrations during nucleation events, but a more rigorous analysis is required to 
quantify the contribution of nucleation events to atmospheric $\mathrm{CCN}$ budget.

\section{Model investigations}

\subsection{Overview of existing model studies}

The first model simulations of atmospheric $\mathrm{CCN}$ formation concentrated on the marine boundary layer (MBL), in which $\mathrm{CCN}$ were thought to mainly originate from the sulfur chemistry associated with marine dimethyl sulphide (DMS) emissions (Lin et al., 1992; Raes et al., 1992; Pandis et al., 1994; Russell et al., 1994; Kerminen and Wexler, 1995). While varying in detail by which aerosol microphysical processes were treated, all of these models described the MBL with a zero-dimensional box, in which new aerosol particles were formed by classical binary $\mathrm{H}_{2} \mathrm{SO}_{4}-\mathrm{H}_{2} \mathrm{O}$ or ternary $\mathrm{H}_{2} \mathrm{SO}_{4}$ $\mathrm{H}_{2} \mathrm{O}-\mathrm{NH}_{3}$ nucleation, and the particle growth was driven by gaseous $\mathrm{H}_{2} \mathrm{SO}_{4}$ condensation. The models were able to explain some of the observed features related to the marine aerosol budget, but their real evaluation was hampered by the lack of gaseous sulfuric acid measurements.

Raes (1995) proposed that most CCN present in the MBL are due to the entrainment of particles nucleated in the free troposphere to the MBL and subsequent processing of the entrained particles by non-precipitating MBL clouds. Support for the important role of entrainment was obtained from several model investigations that relied on either zero- or one-dimensional description of the MBL aerosol dynamics (Fizgerald et al., 1998; Capaldo et al., 1999; Katoshevski et al., 1999; Yoon and Brimblecombe, 2002). These and more recent model simulations showed further that the marine $\mathrm{CCN}$ production associated with the DMS chemistry is tied to primary sea-spray emissions in a complicated manner (e.g. Korhonen et al., 2008: Mårtensson et al., 2010). The effect of low-volatile vapors other than sulfuric acid on marine $\mathrm{CCN}$ production, including organic compounds resulting from oceanic isoprene emissions and iodine compounds released by algae, have also been investigated with models of different complexity (O'Dowd and de Leeuw, 2007; Arnold et al., 2009; and references therein). Such vapors have been demonstrated to be able to affect local CCN concentrations, yet their influence on global $\mathrm{CCN}$ production remains uncertain.

After realizing the importance of free-troposphere nucleation for marine $\mathrm{CCN}$ production and, even more so, the high frequency of new particle formation in continental boundary layers (e.g. Kulmala et al., 2004a), a clear need for large-scale model simulations emerged. Pioneering studies in this regard were those by Lucas and Arimoto (2006) and Spracklen et al. (2006), who demonstrated nucleation to be capable of enhancing aerosol number concentrations throughout the global troposphere. The first global model study on CCN production due to atmospheric nucleation was that by Spracklen et al. (2008a), after which several other model investigations relying on different nucleation mechanisms were conducted. Some of these studies focused solely on $\mathrm{CCN}$ number concentrations in the global atmosphere (Spracklen et al., 2008a; Merikanto et al., 2009; Pierce and Adams, 2009; Yu and Luo, 2009; Luo and Yu, 2011a), while others examined also changes in cloud droplet number concentrations and resulting climatic variables (Makkonen et al., 2009; Wang and Penner, 2009; Kazil et al., 2010; Merikanto et al., 2010). Evaluation of these models was mainly based on comparing modeled total particle number concentrations, and in some cases size distributions, with those measured at surface monitoring sites and by ships or aircraft (e.g. Spracklen et al., 2010; Yu, 2011).

Although the models simulating the production of $\mathrm{CCN}$ in the global atmosphere differ considerably in terms of how nucleation and other aerosol processes are treated, the results from the conducted model investigations share a number of common features. First, nucleation taking place in the upper free troposphere appears to be a major source of CCN in the global troposphere. After transport and growth, these particles dominate frequently $\mathrm{CCN}$ number concentrations in the remote marine boundary layer and contribute to $\mathrm{CCN}$ present in continental background areas. Second, boundarylayer nucleation enhances $\mathrm{CCN}$ number concentrations almost everywhere over the continents. The resulting enhancement, while rather small over areas with substantial primary particle emissions, may be several-fold in environments such as the summertime boreal forest. Third, organic compounds play a crucial role in the CCN production in continental boundary layers and, possibly, elsewhere due to their ability to grow nucleated particles effectively into larger sizes. Finally, the contribution of nucleation to the total $\mathrm{CCN}$ budget in the troposphere is definitely non-negligible, and it might be even larger than $50 \%$ at water vapor supersaturations approaching $1 \%$.

Model simulations have pointed out that atmospheric CCN production due to nucleation depends in a non-linear way on the nucleation rate, subsequent growth of nucleated particles to larger sizes, and the presence of primary aerosol particles. Both nucleation and growth are very challenging processes to be simulated in large-scale modeling frameworks. In case of nucleation, this is due to our incomplete understanding of the atmospheric nucleation mechanisms (e.g. Kerminen et al., 2010) and due to nucleation taking place in sub-grid scale plumes from sources such as major $\mathrm{SO}_{2}$ emitters (e.g. Junkermann et al., 2011; Luo and Yu, 2011a; Stevens et al., 2012). In the case of nuclei growth, the main challenge is the proper treatment of the chemistry and gas-particle partitioning of organic compounds (Riipinen et al., 2011; Yu, 2011). Primary particles complicate the issue further by acting as a sink for low-volatile vapors and freshly-nucleated particles, and by providing additional $\mathrm{CCN}$ as a result of their aging during atmospheric transportation. 
In order to produce more quantitative estimates on the role of nucleation on atmospheric $\mathrm{CCN}$ populations, more detailed model evaluations relying on atmospheric measurements are necessary. Current observations are representative of regional nucleation events that usually take place over tens to hundreds of kilometers. From the model evaluation point of view, such observations would fit much better to regional or continental-scale models than to global models. Unfortunately, few model simulations of atmospheric CCN production over regional scales have been conducted so far. In the following subsection we will discuss briefly the latest results in this regard and draw some conclusions based on these.

\subsection{Regional model simulations}

Regional-scale simulations of the contribution of nucleation to $\mathrm{CCN}$ number concentrations are scarce, but some pioneering studies have been conducted during the recent years. The first paper simulating both nucleation and CCN production over a regional domain was that by Sotiropoulou et al. (2006), who investigated this phenomenon over two regions in Europe. Jung et al. $(2008,2010)$ developed a regional 3D chemical transport model PMCAMx-UF, which simulates the aerosol number (from $1 \mathrm{~nm}$ to $10 \mu \mathrm{m}$ ) and mass distributions for a variety of chemical components, with a user-selected spatial resolution (e.g. from $36 \times 36 \mathrm{~km}$ to $4 \times 4 \mathrm{~km})$ and temporal resolution of minutes. The detailed description of the aerosol size distribution allows for studies on the impact of nucleation on total aerosol particle and $\mathrm{CCN}$ number concentrations. The model allows the user to select among several different nucleation parametrisations (see, e.g. Kerminen et al., 2010, and references therein). In a later study, Jung et al. (2010) simulated the evolution of aerosol size distributions in the Eastern United States, testing the sensitivity of aerosol number concentrations to regional nucleation events. Regional nucleation events were predicted to increase the total particle number concentrations by a factor of 2.5 in the modeling domain, and regional variations in the sensitivity to nucleation were found to be considerable. The corresponding increases for particles larger than $10 \mathrm{~nm}$ $\left(N_{10}\right)$ and $100 \mathrm{~nm}\left(N_{100}\right)$ were $75 \%$ and $15 \%$, respectively. Interestingly, the increases of $N_{100}$ took place often in areas different than those of the nucleation events. These results suggest that nucleation in the boundary layer and in the lower free troposphere increases $\mathrm{CCN}$ concentrations over the Eastern United States by some tens of percent, as $100 \mathrm{~nm}$ can be thought of as a very conservative upper limit for the smallest CCN size. Luo and Yu (2011b) applied a modeling framework that was very different from that by Jung et al. (2010), but they came to a qualitatively similar conclusion with regard of the importance of nucleation in CCN production over the Eastern United States. Matsui et al. (2011) simulated $\mathrm{CCN}$ production around Beijing, China, and found significant enhancements due to nucleation at supersaturations larger than about $0.2 \%$.
A version of PMCAMx-UF simulating the European domain was developed within the European integrated project EUCAARI (Kulmala et al., 2011b; Fountoukis et al., 2012). Fountoukis et al. (2012) used three different nucleation parameterizations and newly developed primary particle number emission inventories to test the sensitivity of particle concentrations in the European boundary layer to nucleation and emissions of $\mathrm{SO}_{2}$ (as nucleation precursor) and primary particle emissions. They found a considerable contribution (roughly a factor of 3 ) of regional nucleation to $>3 \mathrm{~nm}$ number concentrations. For larger particles, considerable regional differences were found depending on the availability of condensable vapors. Nucleation in the boundary layer and in the lower free troposphere was found to have a significant effect (increase of up to a factor of two) on the concentrations of particles larger than $50 \mathrm{~nm}$ in diameter in areas where vapors were available to grow the nucleated particles. For particles larger than $100 \mathrm{~nm}$ the effect of nucleation varied spatially from a $20 \%$ increase in the eastern Mediterranean to $20 \%$ decrease in southern Spain and Portugal, resulting in only a modest average contribution of about $1 \%$ over the whole European domain. However, the model could not capture well the contribution of organics to the early growth of fresh nuclei. These results highlight the need for accurately representing the growth of the nucleation mode particles in order to capture the secondary contribution to $\mathrm{CCN}$ number concentrations.

\subsection{Climatic implications}

The observations and modeling work presented in previous sections have clearly demonstrated that nucleation contributes to the concentration of $\mathrm{CCN}$ sized particles in the atmosphere. Despite this, its effects on atmospheric radiation fluxes and thus on climate remain poorly constrained. Global estimates based on observations are extremely challenging, since satellites and other remote sensing instruments detect only particles larger than $\sim 100 \mathrm{~nm}$, and cannot differentiate the fractional contribution of nucleation in this size range (e.g. Kulmala et al., 2011a). On the other hand, only a few global model studies have thus far investigated the topic (Wang and Penner, 2009; Kazil et al., 2010; Fatima et al., 2011; Makkonen et al., 2012a, b).

Kazil et al. (2010) estimated that the total contribution of nucleation (including direct, semidirect and indirect effects) to the present-day net short-wave radiation at the top of the atmosphere (TOASW) is about $1 \%\left(-2.55 \mathrm{~W} \mathrm{~m}^{-2}\right)$. This is a significant contribution, and it is likely to have changed since the preindustrial times because emissions of gas-phase compounds responsible for nucleation and subsequent growth, as well as of primary particles acting as a sink for nucleated particles, have changed due to e.g. industrialization and land use changes. It is, therefore, probable that the nucleation process contributes to current aerosol radiative forcing (present-day aerosol effect compared to preindustrial time), 
and hence to climate change. This is supported by Makkonen et al. (2012a) who found the predicted aerosol forcing to increase from -1.03 to $-1.61 \mathrm{~W} \mathrm{~m}^{-2}$ when nucleation was included in their model.

Three other climate model studies that have looked at the effect of nucleation on radiative forcing (present day compared to pre-industrial) have highlighted that the lack of a mechanistic understanding of the atmospheric nucleation process leads to a large uncertainty in the simulated aerosol indirect effect. Fatima et al. (2011) tested two ion-nucleation mechanisms and found a total indirect aerosol forcing of -1.42 and $-1.54 \mathrm{~W} \mathrm{~m}^{-2}$, while Wang and Penner (2009) obtained first indirect forcing estimates ranging from -1.22 to $-2.03 \mathrm{~W} \mathrm{~m}^{-2}$ depending on their treatment of free tropospheric and boundary layer nucleation. The latter study also found that the effect of nucleation on the radiative forcing is highly sensitive to the relative change of primary particle and nucleation precursor emissions from the preindustrial times. In addition, Makkonen et al. (2012b) found that the simulated effect of nucleation on aerosol forcing depends also on the model used for biogenic volatile organic compound (BVOC) emissions. They estimated the shortwave cloud forcing to vary between -1.41 and $-1.75 \mathrm{~W} \mathrm{~m}^{-2}$ depending on the nucleation mechanism and used BVOC emission model.

Predictions of future climatic effects of nucleation are further complicated by potential feedback mechanisms concerning both the nucleation mechanism and naturally emitted nucleation precursors (Kulmala et al., 2004c; Arneth et al., 2010; Carslaw et al., 2010). For example, atmospheric nucleation rates are typically found to decrease with increasing ambient temperature, which may lead to a decline in nucleation rates and $\mathrm{CCN}$ number in the coming decades (Yu et al., 2012). On the other hand, modeling studies have predicted both increasing and decreasing future emission trends for DMS and BVOCs, both of which are important precursors for nucleation and growth (Bopp et al., 2004; Arneth et al., 2007; Heald et al., 2009; Cameron-Smith et al., 2011). Given all these uncertainties, it seems evident that improvements both in the process-level understanding of atmospheric nucleation as well as in emission mechanisms of sulfur-containing compounds, organic compounds and primary particulates are essential in order to reduce the uncertainty related to climate effects of nucleation.

\section{Concluding remarks and outlook}

Based on available field measurements and large-scale model simulations, we may conclude that cloud condensation nuclei $(\mathrm{CCN})$ production associated with atmospheric nucleation is both frequent and widespread phenomenon in many types of continental boundary layers. The same is probably true over a large fraction of the free troposphere as well, but confirming this matter awaits further support from atmospheric measurements. The contribution of nucleation to the global CCN budget spans a relatively large uncertainty range, which, together with our poor understanding of aerosol-cloud interactions, results in major uncertainties in the radiative forcing by atmospheric aerosols. In the following, we identify the key areas which, in our opinion, require further attention and research activities.

\subsection{Factors controlling atmospheric $\mathrm{CCN}$ production}

From the process-level point of view, $\mathrm{CCN}$ production associated with atmospheric nucleation is affected by three quantities: the nucleation rate, the growth rate of nucleated particles, and the rate by which growing particles are removed by coagulation or deposition.

Most of the available investigations suggest that atmospheric CCN concentrations tend to be more sensitive to the particle growth rate than to the atmospheric nucleation rate. Addressing the extent to which this is true in different environments and conditions requires a better mechanistic understanding of atmospheric nucleation than what we have today. Both nucleation and particle growth are dictated by aerosol precursor vapor concentrations, more specifically those of sulfuric acid, low-volatile organic compounds, ammonia and amines (see Sect. 2.2). Quantification of atmospheric CCN production resulting from nucleation is not possible until we learn how this process is connected with the availability of these vapors.

Primary particle emissions influence all the three processrelated quantities mentioned above, and especially their relative importance in atmospheric CCN production (Pierce and Adams, 2009; Spracklen et al., 2010, 2011a). More information is clearly needed on the global emission rates of primary aerosol particles, on their number size distribution, and on the spatial and temporal variability of the emissions.

Clouds themselves are able to influence atmospheric CCN production by changing directly atmospheric aerosol and trace gas concentrations, by affecting mixing and the boundary layer-free troposphere exchange, and by influencing the rates of chemical reactions taking place in the atmosphere. Very few, if any, studies have attempted to evaluate the role of clouds in atmospheric $\mathrm{CCN}$ production.

\subsection{Differentiating between primary and secondary CCN}

It takes from a few hours up to several days before particles nucleated in the atmosphere reach sizes at which they are able to act as CCN (see Sect. 2.2). This means that the nucleated particles are usually transported far away from where they were initially formed before becoming $\mathrm{CCN}$, and that they are practically always mixed with $\mathrm{CCN}$ originating from primary particle sources. These features have immediate consequences for investigating atmospheric $\mathrm{CCN}$ formation.

The field studies published so far have had limited capabilities in differentiating between primary and secondary 
$\mathrm{CCN}$, which prevents us from making any quantitative estimates on the contribution of atmospheric nucleation to regional $\mathrm{CCN}$ budgets. In order to improve the situation, more versatile measurements of atmospheric $\mathrm{CCN}$ production are clearly needed. The simplest way to do this is to measure aerosol volatility and use the non-volatile aerosol number as an indication of primary particles (e.g. Reddington et al., 2011). A more ideal approach is to measure simultaneously the particle number size distribution down to a few $\mathrm{nm}$ and preferably below $3 \mathrm{~nm}$ diameter, $\mathrm{CCN}$ spectrum, aerosol chemical composition and mixing state, concentrations of the main aerosol pre-cursor vapors, and main meteorological variables. Vertically-resolved information on these quantities would be highly beneficial as well. In addition to this, we should develop further the methods by which atmospheric $\mathrm{CCN}$ production is being analyzed based on field measurements.

From the modeling point of view, a major issue that has not attracted enough attention is how $\mathrm{CCN}$ resulting from nucleation should actually be defined. In global models, for example, a fraction of aerosol particles formed by atmospheric nucleation are counted as primary aerosol particles. This fraction may be very large downwind of power plants, the plumes of which may be very active locations for nucleation (Junkermann et al., 2011; Luo and Yu, 2011a; Stevens et al., 2012), or in areas affected by biomass burning (Hennigan et al., 2012).

\subsection{Combining different approaches}

There is currently a major gap between the two main approaches used to investigate $\mathrm{CCN}$ production resulting from atmospheric nucleation: field measurements and modeling. Existing field investigations provide a regional view of this phenomenon, the spatial scale of which depends on the characteristics of the measurement site, whereas the vast majority of model studies reported so far operate in a global scale. We recommend two ways to narrow down this gap. First, results from large-scale model simulations should be compared systematically with long-term field measurements from multiple sites. Such a comparison should include as many relevant quantities as possible related to this phenomenon, such as nucleation or aerosol formation rate, particle growth rate, $\mathrm{CCN}$ concentration or some proxy for it and, if possible, the formation rate of new CCN. Second, analyses of field measurements should be aided with model simulations. The best option in such an exercise would be to employ models of different complexity, including a large-scale model, preferably a regional one, and a model capable of taking into account local meteorological features affecting the aerosol dynamics around the measurement site. Simple process model simulations might bring new insight into interpreting field measurements, whereas high-resolution regional models could be used to investigate how reliable field studies are in quantifying the $\mathrm{CCN}$ production from new particle formation events.
Satellites are increasingly being used together with in situ measurements and large-scale model simulations in various climate and air quality applications (e.g. Martin, 2008; Myhre et al., 2009). The small size of nucleated particles poses a major challenge in applying remote sensing for investigating the connection between atmospheric nucleation and $\mathrm{CCN}$ production. Approaches for tracking nucleation mode particles and CCN from space have, however, been suggested (Andreae, 2009; Kulmala et al., 2011a), so this issue is worth being explored in more detail. In addition to satellite data, active remote sensing from the Earth's surface provides many kinds of vertically-resolved data that might be useful in investigating atmospheric nucleation and resulting $\mathrm{CCN}$ production.

\subsection{Atmospheric nucleation, $\mathrm{CCN}$ formation and climate}

With the exception of a few observation-based estimates limited to boreal forest environments (Kurten et al., 2003; Kerminen et al., 2005; Lihavainen et al., 2009), our understanding of the impact of atmospheric nucleation on climate relies on large-scale model simulations (see Sect. 4.3). The available studies agree in general that the direct radiative perturbation resulting from atmospheric nucleation is minor, both locally and in the global atmosphere. This topic may, however, merit some further research in light of the recent results ( $\mathrm{Yu}$ et al., 2012). The indirect radiative perturbation caused by atmospheric nucleation may be quite significant, especially under clean or moderately-polluted conditions, but the associated uncertainties are too large for drawing any definite conclusions at the moment.

A further complication in quantifying the climatic effects of atmospheric nucleation and resulting $\mathrm{CCN}$ production comes from the fact that this phenomenon involves both anthropogenic and natural precursor vapors. Precursors like sulfuric acid can, in principle, be tracked down to either of these two source types using existing modeling frameworks. The same is not true for organic vapors responsible for the growth of nucleated particles: while the vast majority of atmospheric organic compounds are likely to originate from biogenic sources, the processes leading to low-volatility organic vapors seem to be tightly coupled with anthropogenic activities (Spracklen et al., 2011b; Heald et al., 2011).

Finally, no model investigations simulating the full climate feedback cycles suggested to be associated with atmospheric nucleation and resulting $\mathrm{CCN}$ formation have been performed up to date. In spite of the major uncertainties involved, such investigations should definitely be conducted in order to prioritize future research and to assist the evaluation of most effective emission control measures from both climate and air quality point of view. 
Acknowledgements. This work has been supported by European commission $6^{\text {th }}$ Framework program projects EUCAARI (contract no. 036833-2) and EUSAAR (contract no. 026140) and the 7th Framework project PEGASOS. The financial support by the Academy of Finland Centre of Excellence program (project no. 1118615) and by the Maj and Tor Nessling Foundation is also gratefully acknowledged.

Edited by: R. Krejci

\section{References}

Abdul-Razzak, H. and Ghan, S. J.: Influence of slightly soluble organics on aerosol activation, J. Geophys. Res., 110, D06206, doi:10.1029/2004JD005324, 2005.

Adams, P. J. and Seinfeld, J. H.: Disproportionate impact of particulate emissions on global cloud condensation nuclei concentrations, Geophys. Res. Lett., 30, 1239, doi:10.1029/2002GL016303, 2003.

Andreae, M. O.: Correlation between cloud condensation nuclei concentration and aerosol optical thickness in remote and polluted regions, Atmos. Chem. Phys., 9, 543-556, doi:10.5194/acp-9-543-2009, 2009.

Andreae, M. O. and Rosenfeld, D.: Aerosol-cloud-precipitation interactions. Part 1. The nature and sources of cloud-active aerosols, Earth Sci. Rev., 89, 13-41, 2008.

Anttila, T., Kerminen, V.-M., Kulmala, M., Laaksonen, A. and O'Dowd, C.: Modelling the formation of organic particles in the atmosphere, Atmos. Chem. Phys., 4, 1071-1083, doi:10.5194/acp-4-1071-2004, 2004.

Anttila, T., Vaattovaara, P., Komppula, M., Hyvärinen, A.-P., Lihavainen, H., Kerminen, V.-M., and Laaksonen, A.: Sizedependent activation of aerosols into cloud droplets at a subarctic background site during the second Pallas Cloud Experiment (2nd PaCE): method development and data evaluation, Atmos. Chem. Phys., 9, 4841-4854, doi:10.5194/acp-9-4841-2009, 2009.

Anttila, T., Kerminen, V.-M., and Lehtinen, K. E. J.: Parameterizing the formation rate of new particles: the effect of nuclei selfcoagulation, J. Aerosol Sci., 41, 621-636, 2010.

Arneth, A., Miller, P. A., Scholze, M., Hickler, T., Schurgers, G., Smith, B., and Prentice, I. C.: $\mathrm{CO}_{2}$ inhibition of global terrestrial isoprene emissions: Potential implications for atmospheric chemistry, Geophys. Res. Lett., 34, 18813, doi:10.1029/2007GL030615, 2007.

Arneth, A., Harrison, S. P., Zaehle, S., Tsigaridis, K., Menon, S., Bartlein, P. J., Feichter, J., Korhola, A., Kulmala, M., O'Donnell, D., Shurgers, G., Sorvari, S., and Vesala, T.: Terrestial biogeochemical feedbacks in the climate system, Nat. Geosci., 3, 525532, 2010.

Arnold, S. R., Spracklen, D. V., Williams, J., Yassaa, N., Sciare, J., Bonsang, B., Gros, V., Peeken, I., Lewis, A. C., Alvain, S., and Moulin, C.: Evaluation of the global oceanic isoprene source and its impact on marine organic carbon aerosol, Atmos. Chem. Phys., 9, 1253-1262, doi:10.5194/acp-9-1253-2009, 2009.

Asmi, E., Kivekäs, N., Kerminen, V.-M., Komppula, M., Hyvärinen, A.-P., Hatakka, J., Viisanen, Y. \& Lihavainen, H.: Secondary new particle formation in Northern Finland Pallas site between the years 2000 and 2010, Atmos. Chem. Phys., 11, 12959-12972, doi:10.5194/acp-11-12959-2011, 2011a.
Asmi, A., Wiedensohler, A., Laj, P., Fjaeraa, A.-M., Sellegri, K., Birmili, W., Weingartner, E., Baltensperger, U., Zdimal, V., Zikova, N., Putaud, J.-P., Marinoni, A., Tunved, P., Hansson, H.C., Fiebig, M., Kiveks, N., Lihavainen, H., Asmi, E., Ulevicius, V., Aalto, P. P., Swietlicki, E., Kristensson, A., Mihalopoulos, N., Kalivitis, N., Kalapov, I., Kiss, G., de Leeuw, G., Henzing, B., Harrison, R. M., Beddows, D., O’Dowd, C., Jennings, S. G., Flentje, H., Weinhold, K., Meinhardt, F., Ries, L., and Kulmala, M.: Number size distributions and seasonality of submicron particles in Europe 2008-2009, Atmos. Chem. Phys., 11, 5505-5538, doi:10.5194/acp-11-5505-2011, 2011 b.

Benson, D. R., Young, L.-H., Lee, S.-H., Campos, T. L., Rogers, D. C., and Jensen, J.: The effects of airmass history on new particle formation in the free troposphere: case studies, Atmos. Chem. Phys., 8, 3015-3024, doi:10.5194/acp-8-3015-2008, 2008.

Berndt, T., Stratmann, F., Sipilä, M., Vanhanen, J., Petäjä, T., Mikkilä, J., Grüner, A., Spindler, G., Mauldin III, R. L., Curtius, J., Kulmala, M., and Heintzenberg, J.: Laboratory study on new particle formation from the reaction $\mathrm{OH}+\mathrm{SO}_{2}$ : influence of experimental conditions, $\mathrm{H}_{2} \mathrm{O}$ vapour, $\mathrm{NH}_{3}$ and the amine tert-butylamine on the overall process, Atmos. Chem. Phys., 10, 7101-7116, doi:10.5194/acp-10-7101-2010, 2010.

Bigg, E. K. and Leck, C.: Cloud-active particles over the central Arctic Ocean, J. Geophys. Res., 106, 32155-32166, 2001.

Bopp, L., Boucher, O., Aumont, O., Belviso, S., Dufresne, J.-L., Pham, M., and Monfray, P.: Will marine dimethylsulfide emissions amplify or alleviate global warming? A model study, Can. J. Fish. Aquat. Sci., 61, 826-835, 2004.

Boulon, J., Sellegri, K., Venzac, H., Picard, D., Weingartner, E., Wehrle, G., Collaud coen, M., Bütikofer, R., Flückiger, E., Baltensperger, U., and Laj, P.: New particle formation and ultrafine charged aerosol climatology at a high altitude site in the Alps (Jungfraujoch, $3580 \mathrm{~m}$ a.s.1., Switzerland), Atmos. Chem. Phys., 10, 9333-9349, doi:10.5194/acp-10-9333-2010, 2010.

Brock, C. A., Washenfelder, R. A., Trainer, M., Ryerson, T. B., Wilson, J. C., Reeves, J. M., Huey, L. G., Holloway, J. S., Parrish, D. D., Hübler, G., and Fehsenfeld, F. C.: Particle growth in the plumes of coal-fired power plants, J. Geophys. Res., 107, 4155, doi:10.1029/2001JD001062, 2002.

Buenrostro Mazon, S., Riipinen, I., Schultz, D., Valtanen, M., Dal Maso, M., Sogacheva, L., Junninen, H., Nieminen, T., Kerminen, V-M., and Kulmala, M.: Classifying previously undefined days from eleven years of aerosol-particle-size distribution data from the SMEAR II station, Hyytiälä, Finland, Atmos. Chem. Phys., 9, 667-676, doi:10.5194/acp-9-667-2009, 2009.

Cameron-Smith, P., Elliott, S., Maltrud, M., Erikson, D., and Wingenter, O: Changes in dimethyl sulfide oceanic distribution due to climate change, Geophys. Res. Lett., 38, 07704, doi:10.1029/2011GL047069, 2011.

Capaldo, K. P., Kasibhatla, P., and Pandis, S. N.: Is aerosol production within the remote marine boundary layer sufficient to maintain observed concentrations?, J. Geophys. Res., 104, 34833500, 1999.

Carslaw, K. S., Boucher, O., Spracklen, D. V., Mann, G. W., Rae, J. G. L., Woodward, S., and Kulmala, M.: A review of natural aerosol interactions and feedbacks within the Earth system, Atmos. Chem. Phys., 10, 1701-1737, doi:10.5194/acp-10-17012010, 2010. 
Cerully, K. M., Raatikainen, T., Lance, S., Tkacik, D., Tiitta, P., Petäjä, T., Ehn, M., Kulmala, M., Worsnop, D. R., Laaksonen, A., Smith, J. N., and Nenes, A.: Aerosol hygroscopicity and CCN activation kinetics in a boreal forest environment during the 2007 EUCAARI campaign, Atmos. Chem. Phys., 11, 12369-12386, doi:10.5194/acp-11-12369-2011, 2011.

Clarke, A. D.: Atmospheric nuclei in the Pacific midtroposphere: their nature, concentration, and evolution, J. Geophys. Res., 98, 20633-20647, 1993.

Creamean, J. M., Ault, A. P., Ten Hoeve, J. E., Jacobson, M. Z., Roberts, G. C., and Prather, K. A.: Measurements of aerosol chemistry during new particle formation events at a remote rural mountain site, Environ. Sci. Technol., 45, 8208-8216, 2011.

Dal Maso, M., Kulmala, M., Riipinen, I., Wagner, R., Hussein, T., Aalto, P. P., and Lehtinen, K. E. J.: Formation and growth of fresh atmospheric aerosols: eight years of aerosol size distribution data from SMEAR II, Hyytiälä, Finland, Boreal. Environ. Res., 10, 323-336, 2005.

Dal Maso, M., Sogacheva, L., Aalto, P. P., Riipinen, I., Komppula, M., Tunved, P., Korhonen, L., Suur-Uski, V., Hirsikko, A., Kurten, T., Kerminen, V.-M., Lihavainen, H., Viisanen, Y., Hansson, H.-C., and Kulmala, M.: Aerosol size distribution measurements at four Nordic field stations: identification, analysis and trajectory analysis of new particle formation bursts, Tellus B, 59, 350-361, 2007.

Delene, D. J. and Deshler, T.: Vertical profiles of cloud condensation nuclei above Wyoming, J. Geophys. Res., 106, 12579-12588, 2001.

Deng, Z. Z., Zhao, C. S., Ma, N., Liu, P. F., Ran, L., Xu, W. Y., Chen, J., Liang, Z., Liang, S., Huang, M. Y., Ma, X. C., Zhang, Q., Quan, J. N., Yan, P., Henning, S., Mildenberger, K., Sommerhage, E., Schäfer, M., Stratmann, F., and Wiedensohler, A.: Size-resolved and bulk activation properties of aerosols in the North China Plain, Atmos. Chem. Phys., 11, 3835-3846, doi:10.5194/acp-11-3835-2011, 2011.

Detwiler, A., Langerud, D., and Depue, T.: Investigation of the variability of cloud condensation nuclei concentrations at the surface in Western North Dakota, J. Appl. Meteorol. Clim., 49, 136-145, 2010.

Dusek, U., Frank, G. P., Hildebrandt, L, Curtius, J., Schneider, J., Walter, S., Chand, D., Drewnick, F., Hings, S., Jung, D., Bormann, S., and Andreae, M. O.: Size matters more than chemistry for cloud-nucleating ability of aerosol particles, Science, 312, 1375-1378, 2006.

Dusek, U., Frank, G. P., Curtius, J., Drewnick, F., Schneider, J., Kürten, A., Rose, D., Andreae, M. O., Borrmann, S., and Pöschl, U.: Enhanced organic mass fraction and decreased hygroscopicity of cloud condensation nuclei (CCN) during new particle formation events, Geophys. Res. Lett., 37, 03804, doi:10.1029/2009GL040930, 2010.

Ervens, B., Cubison, M. J., Andrews, E., Feingold, G., Ogren, J. A., Jimenez, J. L., Quinn, P. K., Bates, T. S., Wang, J., Zhang, Q., Coe, H., Flynn, M., and Allan, J. D.: CCN predictions using simplified assumptions of organic aerosol composition and mixing state: a synthesis from six different locations, Atmos. Chem. Phys., 10, 4795-4807, doi:10.5194/acp-10-4795-2010, 2010.

Facchini, M. C., Mircea, M., Fuzzi, S., and Charlson, R. J.: Cloud albedo enhancement by surface-active organic solutes in growing droplets, Nature, 401, 257-259, 1999.
Fatima, H., Upadhyaya, H. C., Tripathi, S. N., Sharma O. P., and Yu, F.: On radiative forcing of sulphate aerosol produced from ion-promoted nucleation mechanisms in an atmospheric global model, Meteorol. Atmos. Phys., 112, 101-115, 2011.

Fitzgerald, J. W., Marti, J. J., Hoppel, W. A., Frick, G. M., and Gelbard, F.: A one-dimensional sectional model to simulate multicomponent aerosol dynamics in the marine boundary layer 2 . Model development, J. Geophys. Res., 103, 16103-16117, 1998.

Fors, E. O., Swietlicki, E., Svenningsson, B., Kristensson, A., Frank, G. P., and Sporre, M.: Hygroscopic properties of the ambient aerosol in southern Sweden - a two year study, Atmos. Chem. Phys., 11, 8343-8361, doi:10.5194/acp-11-8343-2011, 2011.

Forster, P., Ramaswamy, V., Artaxo, P., Berntsen, T., Betts, R., Fahey, D. W., Haywood, J., Lean, J., Lowe, D. C., Myhre, G., Nganga, J., Prinn, R., Raga, G., Schulz, M., and Van Dorland, R.: Cheanges in Atmospheric Constituents and in Radiative Forcing. In: Climate Change 2007: The Physical Science Basis. Contribution of Working Group I to the Fourth Assessment Report of the Intergovernmental Panel on Climate Change, edited by: Solomon, S., Qin, D., Manning, M., Chen, Z., Marquis, M., Averyt, K. B., Tignor, M., and Miller, H. L., Cambridge University Press, Cambridge, UK and New York, NY, USA, 2007.

Fountoukis, C., Riipinen, I., Denier van der Gon, H. A. C., Charalampidis, P. E., Pilinis, C., Wiedensohler, A., O’Dowd, C. D., Putaud, J. P., Moerman, M., and Pandis, S. N.: Simulating ultrafine particle formation in Europe using a regional CTM: contribution of primary emissions versus secondary formation to aerosol number concentrations, Atmos. Chem. Phys., 12, 86638677, doi:10.5194/acp-12-8663-2012, 2012.

Furutani, H., Dall'osto, M., Roberts, G. C., and Prather, K. A.: Assessment of the relative importance of atmospheric aging on $\mathrm{CCN}$ activity derived from field observations, Atmos. Environ., 42, 3130-3142, 2008.

Ghan, S. J., Abdul-Razzak, H., Nenes, A., Ming, Y., Liu, X., Ovchinnikov, M., Shipway, B., Mekhidze, N., Xu, J., and Shi, X.: Droplet nucleation: Physically-based parameterizations and comparative evaluation, J. Adv. Model. Earth Syst., 3, M10001, doi:10.1029/2011MS000074, 2011.

Goldstein, A. H. and Galbally, I. E.: Known and unexplored organic constituents in the Earth's atmosphere, Environ. Sci. Technol., 41, 1514-1521, 2007.

Gunthe, S. S., M. King, D. Rose, Q. Chen, P. Roldin, D. K. Farmer, J. L. Jimenez, P. Artaxo, M. O. Andreae, S. T. Martin, and U. Pöschl (2009) Cloud condensation nuclei in pristine tropical rainforest air of Amazonia: size-resolved measurements and modeling of atmospheric aerosol composition and CCN activity. Atmos. Chem. Phys., 9, 7551-7575, doi:10.5194/acp-9-7551-2009, 2009.

Gunthe, S. S., Rose, D., Su, H., Garland, R. M., Achtert, P., Nowak, A., Wiedensohler, A., Kuwata, M., Takegawa, N., Kondo, Y., Hu, M., Shao, M., Zhu, T., Andreae, M. O., and Pöschl, U.: Cloud condensation nuclei (CCN) from fresh and aged air pollution in the megacity region of Beijing, Atmos. Chem. Phys., 11, 11023-11039, doi:10.5194/acp-1111023-2011, 2011.

Hallquist, M., Wenger, J. C., Baltensperger, U., Rudich, Y., Simpson, D., Claeys, M., Dommen, J., Donahue, N. M., George, C., Goldstein, A. H., Hamilton, J. F., Herrmann, H., Hoffmann, T., Inuma, Y., Jang, M., Jenkin, M. E., Jimenez, J. L., 
Kiendler-Scharr, A., Maenhaut, W., McFiggans, G., Mentel, Th. F., Monod, A., Prevot, A. S. H., Seinfeld, J. H., Surratt, J. D., Szmigielski, R., and Wildt, J.: The formation, properties and impact of secondary organic aerosol: current and emerging issues, Atmos. Chem. Phys., 9, 5155-5236, doi:10.5194/acp-9-51552009, 2009.

Hamed, A., Birmili, W., Joutsensaari, J., Mikkonen, S., Asmi, A., Wehner, B., Spindler, G., Jaatinen, A., Wiedensohler, A., Korhonen, H., Lehtinen, K. E. J., and Laaksonen, A.: Changes in the production rate of secondary aerosol particles in Central Europe in view of decreasing $\mathrm{SO}_{2}$ emissions between 1996 and 2006, Atmos. Chem. Phys., 10, 1071-1091, doi:10.5194/acp-10-10712010, 2010.

Hari, P. and Kulmala, M.: Station for Measuring EcosystemAtmosphere Relations (SMEAR II), Boreal Environ. Res., 10, 315-322, 2005.

Hatakka, J., Aalto, T., Aaltonen, V., Aurela, M., Hakola, H., Komppula, M,. Laurila, T., Lihavainen, H., Paatero, J., Salminen, K., and Viisanen, Y.: Overview of the atmospheric research activities and results at Pallas GAW station, Boreal Environ. Res., 8, 365-384, 2003.

Heald, C. L., Wilkinson, M. J., Monson, R. K., Alo, C. A., Wang, G., and Guenther, A.: Response of isoprene emission to ambient $\mathrm{CO}_{2}$ changes and implications for global budgets, Global Change Biol., 15, 1127-1140, doi:10.1111/j.13652486.2008.01802.x, 2009.

Heald, C. L., Coe, H., Jimenez, J. L., Weber, R. J., Bahreini, R., Middlebrook, A. M., Russell, L. M., Jolleys, M., Fu, T.-M., Allan, J. D., Bower, K. N., Capes, G., Crosier, J., Morgan, W. T., Robinson, N. H., Williams, P. I., Cubison, M. J., DeCarlo, P. F., and Dunlea, E. J.: Exploring the vertical profile of atmospheric organic aerosol: comparing 17 aircraft field campaigns with a global model, Atmos. Chem. Phys., 11, 12673-12696, doi:10.5194/acp-11-12673-2011, 2011.

Hegg, D. A., Covert, D. S., Jonsson, H. H., and Woods, R.: Differentiating natural and anthropogenic cloud condensation nuclei in the California coastal zone, Tellus B, 61, 669-676, 2009.

Heintzenberg, J., Birmili, W., Wiedensohler, A., Nowak, A., and Tuch, T.: Structure, variability and persistence of the submicrometre marine aerosol, Tellus B, 56, 357-367, 2004.

Hennigan, C. J., Westervelt, D. M., Riipinen, I., Engelhart, G. J., Lee, T., Collett Jr, J. L., Pandis, S. N., Adams, P. J., and Robinson, A. L.: New particle formation and growth in biomass burning plumes: An important source of cloud condensation nuclei, Geophys. Res. Lett., 39, 09805, doi:10.1029/2012GL050930, 2012

Henning, S., Weingartner, E., Schmidt, S., Wendisch, M., Gäggeler, H. W., and Baltensperger, U.: Size-dependent aerosol activation at the high-alpine site Jungfraujosch (3580 m a.s.1.), Tellus B, 54, 82-95, 2002.

Hermann, M., Heintzenberg, J., Wiedensohler, A., Zahn, A., Heinrich, G., and Brenninkmeijer, C. A. M.: Meridional distributions of aerosol particle number concentrations in the upper troposphere and lower stratosphere obtained by Civil Aircraft for Regular Investigation of the Atmosphere Based on an Instrument Container (CARIBIC) flights, J. Geophys. Res., 108, 4114, doi:10.1029/2001JD001077, 2003.

Hirsikko, A., Laakso, L., Hõrrak, U., Aalto, P. P., Kerminen, V.M., and Kulmala, M.: Annual and size dependent variation of growth rates and ion concentrations in boreal forest, Boreal Environ. Res., 10, 357-369, 2005.

Hobbs, P. V., Stith, J. L., and Radke, L. F.: Cloud-active nuclei from coal-fired electric power plants and their interaction with clouds, J. Appl. Meteorol., 19, 439-451, 1980.

Hudson, J. G.: Cloud condensation nuclei, J. Appl. Meteorol., 32, 596-607, 1993.

Hudson, J. G.: Variability of the relationship between particle size and cloud-nucleating ability, Geophys. Res. Lett., 34, 08801 , doi:10.1029/2006GL028850, 2007.

Hudson, J. G. and Yum, S. S.: Cloud condensation nuclei spectra and polluted and clean clouds over the Indian Ocean, J. Geophys. Res., 107, 8022, doi:10.1029/2001JD000829, 2002.

Hudson, J. G., Noble, S., and Jha, V.: Stratus cloud supersaturations, Geophys. Res. Lett., 37, 21813, doi:10.1029/2010GL045197, 2010.

Irwin, M., Robinson, N., Allan, J. D., Coe, H., and McFiggans, G.: Size-resolved aerosol water uptake and cloud condensation nuclei measurements as measured above a Southeast Asian rainforest during OP3, Atmos. Chem. Phys., 11, 11157-11174, doi:10.5194/acp-11-11157-2011, 2011.

Jefferson, A.: Empirical estimates of $\mathrm{CCN}$ from aerosol optical properties at four remote sites, Atmos. Chem. Phys., 10, 68556861, doi:10.5194/acp-10-6855-2010, 2010.

Jung, J., Adams, P. J., and Pandis, S. N.: Simulating the size distribution and chemical composition of ultrafine particles during nucleation events, Atmos. Environ., 44, 2248-2259, 2006.

Jung, J., Pandis, S. N., and Adams, P. J.: Evaluation of nucleation theories in a sulfur-rich environment, Aerosol Sci. Technol., 42, 495-504, 2008.

Jung, J., Fountoukis, C., Adams, P. J., and Pandis, S. N.: Simulation of in situ ultrafine particle formation in the eastern United States using PMCAMx-UF, J. Geophys. Res., 115, 03203, doi:10.1029/2009JD012313, 2010.

Junkermann, W., Vogel, B., and Sutton, M. A.: The climate penalty for clean fossil fuel combustion, Atmos. Chem. Phys., 11, 12917-12924, doi:10.5194/acp-11-12917-2011, 2011.

Kammermann, L., Gysel, M., Weingartner, E., Herich, H., Cziczo, D. J., Holst, T., Svenningsson, B., Arneth, A., and Baltensperger, U.: Subarctic atmospheric aerosol composition: 3. Measured and modeled properties of cloud condensation nuclei, J. Geophys. Res., 115, 04202, doi:10.1029/2009JD012447, 2010.

Katoshevski, D., Nenes, A., and Seinfeld, J. H.: A study of processes that govern the maintenance of aerosols in the marine boundary layer, J. Aerosol Sci., 30, 503-532, 1999.

Kaufman, Y. J. and Koren, I.: Smoke and pollution aerosol effect on cloud cover, Science, 313, 655-658, 10.1126/science.1126232, 2006.

Kazil, J., Stier, P., Zhang, K., Quaas, J., Kinne, S., O’Donnell, D., Rast, S., Esch, M., Ferrachat, S., Lohmann, U., and Feichter, J.: Aerosol nucleation and its role for clouds and Earth's radiative forcing in the aerosol-climate model ECHAM5-HAM, Atmos. Chem. Phys., 10, 10733-10752, doi:10.5194/acp-1010733-2010, 2010.

Kerminen, V.-M. and Wexler, A. S.: Enhanced formation, and development of sulfate particles due to marine boundary layer circulation, J. Geophys. Res., 100, 23051-23062, 1995.

Kerminen, V.-M., Virkkula, A., Hillamo, R., Wexler, A. S., and Kulmala, M.: Secondary organics and atmospheric cloud condensa- 
tion nuclei production, J. Geophys. Res., 105, 9255-9264, 2000.

Kerminen, V.-M. and Kulmala, M.: Analytical formulae connecting the "real" and the "apparent" nucleation rate and the nuclei number concentration for atmospheric nucleation events, J. Aerosol Sci., 33, 609-622, 2002.

Kerminen, V.-M., Lehtinen, K. E. J., Anttila, T., and Kulmala, M.: Dynamics of atmospheric nucleation mode particles: A time scale analysis, Tellus B, 56, 135-146, 2004.

Kerminen, V.-M., Lihavainen, H., Komppula, M., Viisanen, Y., Kulmala, M. Direct observational evidence linking atmospheric aerosol formation and cloud droplet activation, Geophys. Res. Lett. 32, 14803, doi:10.1029/2005GL023130, 2005.

Kerminen, V.-M., Petäjä, T., Manninen, H. E., Paasonen, P., Nieminen,T., Sipilä, M., Junninen, H., Ehn, M., Gagne, S., Laakso, L., Riipinen, I., Vehkamäki, H., Kurten, T., Ortega, I. K., Dal Maso, M., Brus, D., Hyvärinen, A., Lihavainen, H., Leppä, J., Lehtinen, K. E. J., Mirme, A., Mirme, S., Horrak, U., Berndt, T., Stratmann, F., Birmili, W., Wiedensohler, A., Metzger, A., Dommen, J., Baltensperger, U., Kiendler-Scharr, A., Mentel, T. F., Wildt, J.,Winkler, P. M., Wagner, P. E., Petzold, A., Minikin, A., Plass-Dülmer, C., Pöschl, U., Laaksonen, A., and Kulmala, M.: Atmospheric nucleation: highlights of the EUCAARI project and future directions, Atmos. Chem. Phys., 10, 10829-10848, doi:10.5194/acp-10-10829-2010, 2010.

Khain, A. P.: Notes on the state-of-the-art investigations of aerosol effects on precipitation: a critical review, Environ. Res. Lett., 4, 015004, doi:10.1088/1748-9326/4/1/015004, 2009.

Kim, J. H., Yum, S. S., Shim, S., Yoon, S.-C., Hudson, J. G., Park, J., and Lee, S.-J.: On aerosol hygroscopicity, cloud condensation nuclei $(\mathrm{CCN})$ spectra and critical supersaturation measured at two remote islands of Korea between 2006 and 2009, Atmos. Chem. Phys., 11, 12627-12645, doi:10.5194/acp-1112627-2011, 2011.

Kirkby, J., Curtius, J., Almeida, J., Dunne, E., Duplissy, J., Ehrhart, S., Franchin, A., Gagné, S., Ickes, L., Kürten, A., Kupc, A., Metzger, A., Riccobono, F., Rondo, L., Schobesberger, S., Tsagkogeorgas, G., Wimmer, D., Amorim, A., Bianchi, F., Breitenlechner, M., David, A., Dommen, J., Downard, A., Ehn, M., Flagan, R. C., Haider, S., Hansel, A., Hauser, D., Jud, W., Junninen, H., Kreissl, F., Kvashin, A., Laaksonen, A., Lehtipalo, K., Lima, J., Lovejoy, E. R., Makhutov, V., Mathot, S., Mikkilä, J., Minginette, P., Mogo, S., Nieminen, T., Onnela, A., Pereira, A., Petäjä, T., Schnitzhofer, R., Seinfeld, J. H., Sipilä, M., Stozhkov, Y., Stratmann, F., Tome, A., Vanhanen, J., Viisanen Y., Vrtala, A., Wagner, P. E., Walther, H., Weingartner, E., Wex, H., Winkler, P. M., Carslaw, K. S., Worsnop, D. R., Baltensperger, U., and Kulmala, M.: The role of sulfuric acid, ammonia and galactic cosmic rays in atmospheric aerosol nucleation, Nature, 476, 429-433, 2011.

Kivekäs, N. Sun, J., Zhan, M., Kerminen, V.-M., Hyvärinen, A., Komppula, M., Viisanen, Y., Hong, N., Zhang, Y., Kulmala, M., Zhang, X.-C., Deli-Geer, and Lihavainen, H.: Long term particle size distribution measurements at Mount Waliguan, a highlatitude site in inland China, Atmos. Chem. Phys., 9, 5461-5474, doi:10.5194/acp-9-5461-2009, 2009.

Koch, D. and Del Genio, A. D.: Black carbon semi-direct effects on cloud cover: review and synthesis, Atmos. Chem. Phys., 10, 7685-7696, doi:10.5194/acp-10-7685-2010, 2010.

Komppula, M., Lihavainen, H., Kerminen, V.-M., Kulmala, M., and Viisanen, Y.: Measurements of cloud droplet activation of aerosol particle at a clean subarctic background site, J. Geophys. Res., 110, 06204, doi:10.1029/2004JD005200, 2005.

Korhonen, H., Carslaw, K., Spracklen, D. V., Mann, G. W., and Woodhouse, M. T.: Influence of oceanic dimethyl sulfide emissions on cloud condensation nuclei concentrations and seasonality over the remote Southern Hemisphere oceans: A global model study, J. Geophys. Res., 113, 15204, doi:10.1029/2007JD009718, 2008.

Kristensson, A., Dal Maso, M., Swietlicki, E., Hussein, T., Zhou, J., Kerminen, V.-M., and Kulmala, M.: Characterization of new particle formation events at a background site in Southern Sweden: relation to air mass history, Tellus B, 60, 330-344, 2008.

Kuang, C., McMurry, P. H., and McCormick, A. V.: Determination of cloud condensation nuclei production from measured new particle formation events, Geophys. Res. Lett., 36, 09822 , doi:10.1029/2009GL037584, 2009.

Kuang, C., Riipinen, I., Sihto, S.-L., Kulmala, M., McCormick, A. V., and McMurry, P. H.: An improved criterion for new particle formation in diverse atmospheric environments, Atmos. Chem. Phys., 10, 8469-8484, doi:10.5194/acp-10-8469-2010, 2010.

Kuang, C., Chen, M., Zhao, J., Smith, J., McMurry, P. H., and Wang, J.: Size and time-resolved growth rate measurements of 1 to $5 \mathrm{~nm}$ freshly formed atmospheric nuclei, Atmos. Chem. Phys., 12, 3573-3589, doi:10.5194/acp-12-3573-2012, 2012.

Kulmala, M., Laaksonen, A., Korhonen, P., Vesala, T., Ahonen, T., and Barrett, J. C.: The effect of atmospheric nitric acid vapor on cloud condensation nuclei activation, J. Geophys. Res., 98, 22949-22958, 1993.

Kulmala, M., Toivonen, A., Mäkelä, J., and Laaksonen, A.: Analysis of the growth of nucleation mode particles observed in Boreal forest, Tellus B, 50, 449-462, 1998.

Kulmala, M., Vehkamäki, H., Petäjä, T., Dal Maso, M., Lauri, A., Kerminen, V.-M., Birmili, W., and McMurry, P. H.: Formation and growth rates of ultrafine atmospheric particles: A review of observations, J. Aerosol Sci., 35, 143-176, 2004a.

Kulmala, M., Laakso, L., Lehtinen, K. E. J., Riipinen, I., Dal Maso, M., Anttila, T., Kerminen, V.-M., Hõrrak, U., Vana, M., and Tammet, H.: Initial steps of aerosol growth, Atmos. Chem. Phys., 4, 2553-2560, doi:10.5194/acp-4-2553-2004, 2004b.

Kulmala, M., Suni, T., Lehtinen, K. E. J., Dal Maso, M., Boy, M., Reissell, A., Rannik, U., Aalto, P., Keronen, P., Hakola, H., Back, J. B., Hoffmann, T., Vesala, T., and Hari, P.: A new feedback mechanism linking forests, aerosols, and climate, Atmos. Chem. Phys., 4, 557-562, doi:10.5194/acp-4-557-2004, 2004c.

Kulmala, M., Riipinen, I., Sipilä, M., Manninen, H. E., Petäjä, T., Junninen, H., Dal Maso, M., Mordas, G., Mirme, A., Vana, M., Hirsikko, A., Laakso, L., Harrison, R. M., Hanson, I., Leung, C., Lehtinen, K. E. J., and Kerminen, V.-M.: Toward direct measurement of atmospheric nucleation, Science, 318, 89-92, 2007.

Kulmala, M. and Kerminen, V.-M.: On the formation and growth of atmospheric nanoparticles, Atmos. Res., 90, 132-150, 2008.

Kulmala, M., Arola, A., Nieminen, T., Riuttanen, L., Sogacheva, L., de Leeuw, G., Kerminen, V.-M., and Lehtinen K. E. J.: The first estimates of global nucleation mode aerosol concentrations based on satellite measurements, Atmos. Chem. Phys., 11, 10791-10801, doi:10.5194/acp-11-10791-2011, 2011a.

Kulmala, M., Asmi, A., Lappalainen, H. K., Baltensperger, U., Brenguier, J.-L., Facchini, M. C., Hansson, H.-C., Hov, Ø., O’Dowd, C. D., Pöschl, U., Wiedensohler, A., Boers, R., 
Boucher, O., de Leeuw, G., Denier van den Gon, H., Feichter, J., Krejci, R., Laj, P., Lihavainen, H., Lohmann, U., McFiggans, G., Mentel, T., Pilinis, C., Riipinen, I., Schulz, M., Stohl, A., Swietlicki, E., Vignati, E., Amann, M., Amann, M., Alves, C., Arabas, S., Artaxo, P., Beddows, D. C. S., Bergström, R., Beukes, J. P., Bilde, M., Burkhart, J. F., Canonaco, F., Clegg, S., Coe, H., Crumeyrolle, S., D'Anna, B., Decesari, S., Gilardoni, S., Fischer, M., Fjæraa, A. M., Fountoukis, C., George, C., Gomes, L., Halloran, P., Hamburger, T., Harrison, R. M., Herrmann, H., Hoffmann, T., Hoose, C., Hu, M., Hõrrak, U., Iinuma, Y., Iversen, T., Josipovic, M., Kanakidou, M., KiendlerScharr, A., Kirkeva ${ }^{\circ}$ g, A., Kiss, G., Klimont, Z., Kolmonen, P., Komppula, M., Kristjansson, J.-E., Laakso, L., Laaksonen, A., Labonnote, L., Lanz, V. A., Lehtinen, K. E. J., Makkonen, R., McMeeking, G., Merikanto, J., Minikin, A., Mirme, S., Morgan, W. T., Nemitz, E., O’Donnell, D., Panwar, T. S., Pawlowska, H., Petzold, A., Pienaar, J. J., Pio, C., Plass-Duelmer, C., Prevot, A. S. H., Pryor, S., Reddington, C. L., Roberts, G., Rosenfeld, D., Schwarz, J., Seland, Ø., Sellegri, K., Shen, X. J., Shiraiwa, M., Siebert, H., Sierau, B., Simpson, D., Sun, J. Y., Topping, D., Tunved, P., Vaattovaara, P., Vakkari, V., Veefkind, J. P., Visschedijk, A., Vuollekoski, H., Vuolo, R., Wehner, B., Wildt, J., Woodward, S., Worsnop, D. R., van Zadelhoff, G.-J., Zardini, A. A., Zhang, K., van Zyl, P. G., Kerminen, V.-M., Carslaw, K. S., and Pandis, S. N.: General overview: European Integrated project on Aerosol Cloud Climate and Air Quality interactions (EUCAARI) - integrating aerosol research from nano to global scales, Atmos. Chem. Phys., 11, 13061-13143, doi:10.5194/acp11-13061-2011, 2011b.

Kulmala, M., Petäjä, T., Nieminen, T., Sipilä, M., Manninen, H. E., Lehtipalo, K., Dal Maso, M., Aalto, P. P., Junninen, H., Paasonen, P., Riipinen, I., Lehtinen, K. E. J., Laaksonen, A., and Kerminen, V.-M.: Measurement of the nucleation of atmospheric aerosol particles, Nat. Protoc., 7, 1651-1667, doi:10.1038/nprot.2012091, 2012.

Kumar, P., Sokooik, I. N., and Nenes, A.: Measurements of cloud condensation nuclei activity and droplet kinetics of wet processed regional dust samples and minerals, Atmos. Chem. Phys., 11, 8661-8676, doi:10.5194/acp-11-8661-2011, 2011.

Kurten, T., Kulmala, M., Dal Maso, M., Suni, T., Reissell, A., Vehkamäki, H., Hari, P., Laaksonen, A., Viisanen, Y., and Vesala, T.: Estimation of different forest-related contributions to the radiative balance using observations in southern Finland, Boreal Environ. Res., 8, 275-285, 2003.

Kuwata, M. and Kondo Y.: Dependence of size-resolved CCN spectra on the mixing state of nonvolatile cores observed in Tokyo, J. Geophys. Res., 113, 19202, doi:10.1029/2007JD009761, 2008.

Kuwata, M., Kondo, Y., Miyazaki, Y., Komazaki, Y., Kim, J. H., Yum, S. S., Tanimoto, H., and Matsuedda, H.: Cloud condensation nuclei activity at Jeju Island, Korea in spring 2005, Atmos. Chem. Phys., 8, 2933-2948, doi:10.5194/acp-8-2933-2008, 2008.

Laakso, L., Laakso, H., Aalto, P. P., Keronen, P., Petäjä, T., Nieminen, T., Pohja, T., Siivola, E., Kulmala, M., Kgabi, N., Molefe, M., Mabaso, D., Phalatse, D., Pienaar, K. \& Kerminen, V.-M.: Basic characteristics of atmospheric particles, trace gases and meteorology in a relatively clean Southern African Savannah environment, Atmos. Chem. Phys., 8, 4823-4839, doi:10.5194/acp-8-4823-2008, 2008.
Laakso, L., Merikanto, J., Vakkari, V., Laakso, H., Kulmala, M., Molefe, M., Kgabi, N., Mabaso, D., Carslaw, K. S., Spracklen, D. V., and Kerminen, V.-M.: Boundary layer nucleation as a source of new CCN in savannah environment, Atmos. Chem. Phys. Discuss., 12, 8503-8531, doi:10.5194/acpd-12-8503-2012, 2012.

Laaksonen, A., Hamed, A., Joutsensaari, J., Hiltunen, L., Cavalli, F., Junkermann, W., Asmi, A., Fuzzi, S., and Facchini, M. C.: Cloud condensation nuclei production from nucleation events at a highly polluted region, Geophys. Res. Lett., 32, 06812, doi:10.1029/2004GL022092, 2005.

Laaksonen, A., Kulmala, M., O’Dowd, C. D., Joutsensaari, J., Vaattovaara, P., Mikkonen, S., Lehtinen, K. E. J., Sogacheva, L., Dal Maso, M., Aalto, P., Petäjä, T., Sogachev, A., Yoon, Y. J., Lihavainen, H., Nilsson, D., Facchini, M. C., Cavalli, F., Fuzzi, S., Hoffmann, T., Arnold, F., Hanke, M., Sellegri, K., Umann, B., Junkermann, W., Coe, H., Allan, J. D., Alfarra, M. R. Worsnop, D. R., Riekkola, M.-L., Hyötyläinen, T., and Viisanen, Y.; The role of VOC oxidation products in continental new particle formation, Atmos. Chem. Phys., 8, 2657-2665, doi:10.5194/acp-8-2657-2008, 2008.

Lehtinen, K. E. J., Dal Maso, M., Kulmala, M., Kerminen, V.M.: Estimating nucleation rates from apparent particle formation rates and vice versa: Revised formulation of the KerminenKulmala equation, J. Aerosol Sci., 38, 988-994, 2007.

Leppä, J., Anttila, T., Kerminen, V.-M., Kulmal, M., and Lehtinen, K. E. J.: Atmospheric new particle formation: real and apparent growth of neutral and charged particles, Atmos. Chem. Phys., 11, 4939-4955, doi:10.5194/acp-11-4939-2011, 2011.

Levin, E. J. T., Prenni, A. J., Petters, M. D., Kreidenweis, S. M., Sullivan, R. C., Atwood, S. A., Ortega, J., DeMott, P. J., and Smith, J. N.: An annual cycle of size-resolved aerosol hygroscopicity at a forested site in Colorado, J. Geophys. Res., 117, 06201, doi:10.1029/2011JD016854, 2012.

Lihavainen, H., Kerminen, V.-M., Komppula, M., Hatakka, J., Aaltonen, V., Kulmala, M., and Viisanen, Y.: Production of "potential" cloud condensation nuclei associated with atmospheric newparticle formation in northern Finland, J. Geophys. Res., 108, 4782, doi:10.1029/2003JD003887, 2003.

Lihavainen, H., Kerminen, V.-M., Komppula, M., Hyvärinen, A.-P., Laakia, J., Saarikoski, S., Makkonen, U., Kivekäs, N., Hillamo, R., Kulmala, M., and Viisanen, Y.: Measurements of the relation between aerosol properties and microphysics and chemistry of low level liquid water clouds in Northern Finland, Atmos. Chem. Phys., 8, 6925-6938, doi:10.5194/acp-8-6925-2008, 2008.

Lihavainen, H., Kerminen, V.-M., Tunved, P., Aaltonen, V., Arola, A., Hatakka, J., Hyvärinen, A., and Viisanen, Y.: Observational signature of the direct radiative effect by natural boreal forest aerosols and its relation to the corresponding first indirect effect, J. Geophys. Res., 114, 20206, doi:10.1029/2009JD012078, 2009.

Lin, X, Chameides, W. F., Kiang, C. S., Stelson, A. W., and Berresheim, K.: A model study of the formation of cloud condensation nuclei in the remote marine areas, J. Geophys. Res., 97, 18161-18171, 1992.

Lucas, D. D. and Arimoto, H.: Evaluating aerosol nucleation parameterizations in a global atmospheric model, Geophys. Res. Lett., 33, 10808, doi:10.1029/2006GL025672, 2006.

Luo, G. and Yu, F.: Sensitivity of global cloud condensation nuclei concentrations to primary sulfate emission parameteriza- 
tions, Atmos. Chem. Phys., 11, 1949-1959, doi:10.5194/acp-111949-2011, 2011a.

Luo, G. and Yu, F.: Simulation of particle formation and number concentration over the Eastern United States with the WRFChem + APM model, Atmos. Chem. Phys., 11, 11521-11533, doi:10.5194/acp-11-11521-2011, 2011 b.

Makkonen, R., Asmi, A., Korhonen, H., Kokkola, H., Järvenoja, S., Räisänen, P., Lehtinen, K. E. J., Laaksonen, A., Kerminen, V.M., Järvinen, H., Lohmann, U., Bennartz, R., Feichter, J., and Kulmala, M.: Sensitivity of aerosol concentrations and cloud properties to nucleation and secondary organic distribution in ECHAM5-HAM global circulation model, Atmos. Chem. Phys., 9, 1747-1766, doi:10.5194/acp-9-1747-2009, 2009.

Makkonen, R., Asmi, A., Kerminen, V.-M. , Boy, M., Arneth, A., Hari, P. and Kulmala, M.: Air pollution control and decreasing new particle formation lead to strong climate warming, Atmos. Chem. Phys., 12, 1515-1524, doi:10.5194/acp-12-15152012, 2012a.

Makkonen, R., Asmi, A., Kerminen, V.-M., Boy, M., Arneth, A., Guenther, A., and Kulmala, M.: BVOC-aerosol-climate interactions in the global aerosol-climate model ECHAM5.5-HAM2, Atmos. Chem. Phys., 12, 10077-10096, doi:10.5194/acp-1210077-2012, 2012b.

Manninen, H. E., Nieminen, T., Asmi, E., Gagné, S., Häkkinen, S., Lehtipalo, K., Aalto, P., Vana, M., Mirme, A., Mirme, S., Hõrrak, U., Plass-Dülmer, C., Stange, G., Kiss, G., Hoffer, A., Töro, N., Moermann, M., Henzing, B., de Leeuw, G., Brinkenberg, M., Kouvarakis, G.N., Bougiatioti, K., Mihalopoulos, N., O’Dowd, C., Ceburnis, D., Arneth, A., Svenningsson, B., Swietlicki, E., Tarozzi, L., Decesari, S., Facchini, M.C., Birmili, W., Sonntag, A., Wiedensohler, A., Boulon, J., Sellegri, K., Laj, P., Gysel, M., Bukowiecki, N., Weingartner, E., Laaksonen, A., Hamed, A., Joutsensaari, J., Petäjä, T., Kerminen, V.-M., and Kulmala, M.: EUCAARI ion spectrometer measurements at 12 European sites - analysis of new-particle formation events, Atmos. Chem. Phys., 10, 7907-7927, doi:10.5194/acp-10-7907-2010, 2010.

Martin, R. V.: Satellite remote sensing of surface air quality, Atmos. Environ., 42, 7823-7843, 2008.

Matsui, H., Koike, M., Kondo, Y., Takegawa, N., Wiedensohler, A., Fast, J. D., and Zaveri, R. A.: Impact of new particle formation on the concentrations of aerosols and cloud condensation nuclei around Beijing, J. Geophys. Res., 116, 19208, doi:10.1029/2011JD016025, 2011.

Mårtensson, E. M., Tunved, P., Korhonen, H., and Nilsson, E. D.: The role of sea-salt emissions in controlling the marine Aitken and accumulation model aerosol: a model study, Tellus B, 62, 259-279, 2010.

McComiskey, A., Feingold, G., Frisch, A. S., Turner, D. D., Miller, M. A., Chiu, J. C., Min, Q., and Ogren, J. A.: An assessment of aerosol-cloud interactions in marine stratus clouds based on surface remote sensing, J. Geophys. Res., 114, 09203, doi:10.1029/2008JD011006, 2009.

McFiggans, G., Artaxo, P., Baltensperger, U., Coe, H., Facchini, M.C., Feingold, G., Fuzzi, S., Gysel, M., Laaksonen, A., Lohmann, U., Mentel, T. F., Murphy, D. M., O’Dowd, C. D., Snider, J. R., and Weingartner, E.: The effect of physical and chemical aerosol properties on warm cloud droplet activation, Atmos. Chem. Phys., 6, 2593-2649, doi:10.5194/acp-6-2593-2006, 2006.
McMurry, P., Fink, M, Sakurai, H., Stolzenburg, M., Mauldin, L., Moore, K., Smith, J., Eisele, F., Sjostedt, S., and Tanner, D: A criterion for new particle formation in sulfurrich Atlanta atmosphere, J. Geophys. Res., 110, 22S02, doi:10.1029/2005JD005901, 2005.

Merikanto, J., Spracklen, D. V., Mann, G. W., Pickering, S. J., and Carslaw, K. S.: Impact of nucleation on global CCN. Atmos. Chem. Phys., 9, 8601-8616, doi:10.5194/acp-9-8601-2009, 2009.

Merikanto, J., Spracklen, D. V., Pringle, K. J., and Carslaw, K. S.: Effects of boundary layer particle formation on cloud droplet number and changes in cloud albedo from 1850 to 2000, Atmos. Chem. Phys., 10, 695-705, doi:10.5194/acp-10-695-2010, 2010.

Mochida, M., Nishita-Hara, C., Kitamori, Y., Aggarwal, S. G., Kawamura, K., Miura, K., and Takami, A.: Size-segregated measurements of cloud condensation nucleus activity and hygroscopic growth for aerosols at Cape Hedo, Japan, in spring 2008, J. Geophys. Res., 115, 21207, doi:10.1029/2009JD013216, 2010.

Myhre, G., Berglen, T. F., Jonsrud, M., Hoyle, C. R., Berntsen, T. K., Christopher, S. A., Fahey, D. W., Isaksen, I. S. A., Jones, T. A., Kahn, R. A., Loeb, N., Quinn, P., Remer, L., Schwarz, J. P., and Yttri, K. E.: Modelled radiative forcing of the direct aerosol effect with multi-observation evaluation, Atmos. Chem. Phys., 9, 1365-1392, doi:10.5194/acp-9-1365-2009, 2009.

Nieminen, T., Lehtinen, K. E. J., and Kulmala, M.: sub-10 nm particle growth by vapor condensation - effects of vapor molecule size and particle thermal speed, Atmos. Chem. Phys., 10, 9773 9779, doi:10.5194/acp-10-9773-2010, 2010.

O'Dowd, C. D. and de Leeuw, G.: Marine aerosol production: a review of the current knowledge, Phil. T. R. Soc. A, 365, 17531774, 2007.

O’Dowd, C. D., Monahan, C., and Dall'Osto, M.: On the occurrence of opean ocean particle production and growth events, Geophys. Res. Lett., 37, 19805, doi:10.1029/2010GL044679, 2010.

Pandis, S. N., Russell, L M., and Seinfeld, J. H.: The relation between DMS flux and CCN concentration in remote marine regions, J. Geophys. Res., 99, 16945-16957, 1994.

Penner, J. E., Xu, L., and Wang, M.: Satellite methods underestimate indirect climate forcing by aerosols, P. Natl. Acad. Sci., 108, 13404-13408, doi/10.1073/pnas.1018526108, 2011.

Petters, M. D., and S. M. Kreidenweis, S. M.: A single parameter representation of hygroscopic growth and cloud condensation nucleus activity Atmos. Chem. Phys., 7, 1961-1971, doi:10.5194/acp-7-1961-2007, 2007.

Pierce, J. R. and Adams, P. J.: Efficacy of cloud condensation nuclei formation from ultrafine particles, Atmos. Chem. Phys., 7, 13671379, doi:10.5194/acp-7-1367-2007, 2007.

Pierce, J. R. and Adams, P. J.: Uncertainty in global CCN concentrations from uncertain aerosol nucleation and primary emission rates, Atmos. Chem. Phys., 9, 1339-1356, doi:10.5194/acp9-1339-2009, 2009.

Pierce, J. R., Riipinen, I., Kulmala, M., Ehn, M., Petäjä, T., Junninen, H., Worsnop, D. R., and Donahue, N. M.: Quantification of the volatility of secondary organic compounds in ultrafine particles during nucleation events, Atmos. Chem. Phys., 11, 90199036, doi:10.5194/acp-11-9019-2011, 2011.

Pierce, J. R., Leaitch, W. R., Liggio, J., Westervelt, D. M., Wainwrigth, C. D., Abbatt, J. P. D., Ahlm, L., Al-Basheer, W., Cz- 
iczo, D. J., Hayden, K. L., Lee, A. K. Y., Li, S.-M., Russell, L. M., Sjostedt, S. J., Strawbridge, K. B., Travis, M., Vlasenko, A., Wentzell, J. J. B., Wiebe, H. A., Wong, J. P. S. \& Macdonald, A. M.: Nucleation and condensation growth to $\mathrm{CCN}$ sizes during a sustained pristine biogenic SOA event in a forested mountain site, Atmos. Chem. Phys., 12, 3147-3163, doi:10.5194/acp-123147-2012, 2012.

Pringle, K. J., Tost, H., Pozzer, A., Pöschl, U., and Lelieveld, J.: Global distribution of the effective aerosol hygroscopicity parameter for CCN activation, Atmos. Chem. Phys., 10, 52415255, doi:10.5194/acp-10-5241-2010, 2010.

Prisle, N. L., Raatikainen, T., Laaksonen, A., and Bilde, M.: Surfactants in cloud droplet activation: Mixed organic-inorganic particles, Atmos. Chem. Phys., 10, 5663-5683, doi:10.5194/acp-105663-2010, 2010.

Pye, H. O. T. and Seinfeld, J. H.: A global perspective on aerosol from low-volatility organic compounds, Atmos. Chem. Phys., 10, 4377-4401, doi:10.5194/acp-10-4377-2010, 2010.

Quaas, J., Ming, Y., Menon, S., Takemura, T., Wang, M., Penner, J. E., Gettelman, A., Lohmann, U., Bellouin, N., Boucher, O., Sayer, A. M., Thomas, G. E., McComiskey, A., Feingold, G., Hoose, C., Kristjánsson, J. E., Liu, X., Balkanski, Y., Donner, L. J., Ginoux, P. A., Stier, P., Grandey, B., Feichter, J., Sednev, I., Bauer, S. E., Koch, D., Grainger, R. G., Kirkevåg, A., Iversen, T., Seland, Ø., Easter, R., Ghan, S. J., Rasch, P. J., Morrison, H., Lamarque, J.-F., Iacono, M. J., Kinne, S., and Schulz, M.: Aerosol indirect effects - general circulation model intercomparison and evaluation with satellite data, Atmos. Chem. Phys., 9, 8697-8717, doi:10.5194/acp-9-8697-2009, 2009.

Quinn, P. K., Bates, T. S., Coffman, D. J., and Covert, D.: Influence of particle size and chemistry on the cloud nucleating properties of aerosols, Atmos. Chem. Phys., 8, 1029-1042, doi:10.5194/acp-8-1029-2008, 2008.

Raes, F.: Entrainment of free tropospheric aerosols as a regulating mechanism for cloud condensation nuclei in the remote marine boundary layer, J. Geophys. Res., 100, 2893-2903, 1995.

Raes, F. and Van Dingenen, R.: Simulations of condensation and cloud condensation nuclei from biogenic $\mathrm{SO}_{2}$ in the remote marine boundary layer, J. Geophys. Res., 97, 12901-12912, 1992.

Reddington, C. L., Carslaw, K. S., Spracklen, D. V., Frontoso, M. G., Collins, L., Merikanto, J., Minikin, A., Hamburger, T., Coe, H., Kulmala, M., Aalto, P., Flentje, H., Plass-Dülmer, C., Birmili, W., Wiedensohler, A., Wehner, B., Tuch, T., Sonntag, A., O'Dowd, C. D., Jennings, S. G., Dupuy, R., Baltensperger, U., Weingartner, E., Hansson, H.-C., Tunved, P., Laj, P., Sellegri, K., Boulon, J., Putaud, J.-P., Gruening, C., Swietlicki, E., Roldin, P., Henzing, J. S., Moerman, M., Mihalopoulos, N., Kouvarakis, G., Ždímal, V., Zíková, N., Marinoni, A., Bonasoni, P., and Duchi, R.: Primary versus secondary contributions to particle number concentrations in the European boundary layer, Atmos. Chem. Phys., 11, 12007-12036, doi:10.5194/acp-11-12007-2011, 2011.

Reutter, P., Su, H., Trentmann, J., Simmel, M., Rose, D., Gunthe, S. S., Wernli, H., Andreae, M. O., and Pösch, U: Aerosol- and updraft-limited regimes of cloud droplet formation: influence of particle number, size and hygroscopicity on the activation of cloud condensation nuclei (CCN), Atmos. Chem. Phys., 9, 70677080, doi:10.5194/acp-9-7067-2009, 2009.

Riccobono, F., Rondo, L., Sipilä, M., Barmet, P., Curtius, J., Dommen, J., Ehn, M., Ehrhart, S., Kulmala, M., Kürten, A., Mikkilä,
J., Petäjä, T., Weingartner, E., and Baltensperger, U.: Contribution of sulfuric acid and oxidized organic compounds to particle formation and growth, Atmos. Chem. Phys., 12, 9427-9439, doi:10.5194/acp-12-9427-2012, 2012.

Riipinen, I., Pierce, J. R., Yli-Juuti, T., Nieminen, T., Häkkinen, S., Ehn, M., Junninen, H., Lehtipalo, K., Petäjä, T., Slowik, J., Chang, R., Shantz, N. C., Abbatt, J., Leaitch, W. R., Kerminen, V.-M., Worsnop, D. R., Pandis, S. N., Donahue, N. M., and Kulmala, M.: Organic condensation: a vital link connecting aerosol formation to cloud condensation nuclei (CCN) concentrations, Atmos. Chem. Phys., 11, 3865-3878, doi:10.5194/acp-11-38652011, 2011.

Rissler, J., Svenningsson, B., Fors, E. O., Bilde, M., and Swietlicki, E.: An evaluation and comparison of cloud condensation nucleus activity models: Predicting particle critical saturation from growth at subsaturation, J. Geophys. Res., 115, 22208, doi:10.1029/2010JD014391, 2010.

Roberts, G., Mauger, G., Hadley, O., and Ramanathan, V.: North American and Asian aerosols over the eastern Pacific Ocean and their role in regulating cloud condensation nuclei, J. Geophys. Res., 111, 13205, doi:10.1029/2005JD006661, 2006.

Roberts, G. C., D. A. Day, L. M. Russell, E. J. Dunlea, J. L. Jimenez, J. M. Tomlinson, D. R. Collins, Y. Shinozuka, and A. D. Clarke (2010). Characterization of particle cloud droplet activity and composition in the free troposphere and the boundary layer during INTEX-B, Atmos. Chem. Phys., 10, 6627-6644, doi:10.5194/acp-10-6627-2010, 2010.

Rose, D., Nowak, A., Achtert, P., Wiedensohler, A., Hu, M., Shao, M., Zhang, Y., Andreae, M. O., and Pöschl, U.: Cloud condensation nuclei in polluted air and biomass burning smoke near the mega-city Guangzhou, China - Part 1: Size-resolved measurements and implications for the modeling of aerosol particle hygroscopicity and CCN activity, Atmos. Chem. Phys., 10, 33653383, doi:10.5194/acp-10-3365-2010, 2010.

Rosenfeld, D., Lohmann, U., Raga, G. B., O’Dowd, C. D., Kulmala, M., Fuzzi, S., Reissell, A., and Andreae, M. O.: Flood or drought: How do aerosols affect precipitations?, Science, 321, 1309-1313, 10.1126/science.1160606, 2008.

Russell, L. M., Pandis, S. N., and Seinfeld, J. H.: Aerosol production and growth in the marine boundary layer, J. Geophys. Res., 99, 20989-21003, 2004.

Schwartz, S. E., Charlson, R. J., Kahn, R. A., Ogren, J. A., and Rodhe, H.: Why hasn't Earth warmed as much as expected?, J. Climate, 23, 2453-2464, 2010.

Seinfeld, J. H. and Pandis, S. N.: Atmospheric Chemistry and Physics: From Air Pollution to Climate Change, John Wiley, New York, USA, 1326 pp., 2006.

Shao, H. and Liu, G.: A critical examination of the observed first aerosol indirect effect, J. Atmos. Sci., 66, 1018-1032, 2009.

Shaw, G. E.: Aerosols at a mountaintop observatory in Arizona, J. Geophys. Res., 112, 07206, doi:10.1029/2005JD006893, 2007.

Shulman, M. L., Jacobson, M. C., Carlson, R. J., Synovec, R. E., and Young, T. E.: Dissolution behavior and surface tension effects of organic compounds in nucleating cloud droplets, Geophys. Res. Lett., 23, 277-280, 1996.

Sihto, S.-L., Mikkilä, J., Vanhanen, J., Ehn, M., Liao, L., Lehtipalo, K., Aalto, P. P., Duplissy, J., Petäjä, T., Kerminen, V.-M., Boy, M., and Kulmala, M.: Seasonal variation of CCN concentrations and aerosol activation properties in boreal forest, Atmos. Chem. 
Phys., 11, 13269-13285, doi:10.5194/acp-11-13269-2011, 2011. Singh, H. B., Anderson, B. E., Avery, M. A., Viezee, W., Chen, Y., Tabazadeh, A., Hamill, P., Pueschel, R., Fuelberg, H. E., and Hannan, J. R.: Global distribution and sources of volatile and nonvolatile aerosol in the remote troposphere, J. Geophys. Res., 107, 4121, doi:10.1029/2001JD000486, 2002.

Sipilä, M., Berndt, T., Petäjä, T., Brus, D., Vanhanen, J., Stramann, F., Patokoski, J., Mauldin III, R. L., Hyvärinen, A.P., Lihavainen, H., and Kulmala, M.: The role of sulfuric acid in atmospheric nucleation, Science, 327, 1243-1246, doi:10.1126/science.1180315, 2010.

Small, J. D., Chuang, P. Y., Feingold, G., and Jiang, H.: Can aerosol decrease cloud lifetime?, Geophys. Res. Lett., 36, 16806, doi:10.1029/2009GL038888, 2009.

Smith, J. N., Barsanti, K. C., Friedli, H. R., Ehn, M., Kulmala, M., Collins, D. R., Scheckman, J. H., Williams, B. J., and McMurry, P. H.: Observations of aminium salts in atmospheric nanoparticles and possible climatic implications, P. Natl. Acad. Sci., 107, 6634-6639, 2010.

Snider, J. R., and Brenguier, J.-L.: Cloud condensation nuclei and cloud droplet measurements during ACE-2, Tellus B, 52, 828842,2000

Sorjamaa, R., Svenningsson, B., Raatikainen, T., Henning, S., Bilde, M., and Laaksonen, A.: The role of surfactants in Köhler theory reconsidered, Atmos. Chem. Phys., 4, 2107-2117, doi:10.5194/acp-4-2107-2004, 2004.

Sorjamaa, R. and Laaksonen, A.: The effect of $\mathrm{H}_{2} \mathrm{O}$ adsorption on cloud drop activation of insoluble particles: a theoretical framework, Atmos. Chem. Phys., 7, 6175-6180, doi:10.5194/acp-76175-2007, 2007.

Sorooshian, A., Feingold, G., Lebsock, M. D., Jiang, H., and Stephens, G. L.: On the precipitation susceptibility of clouds to aerosol perturbations, Geophys. Res. Lett., 36, 13803, doi:10.1029/2009GL038993, 2009.

Sotiropoulou, R. E. P., Tagaris, E., Pilinis, C., Anttila, T., and Kulmala, M.: Modeling new particle formation during air pollution episodes: impacts on aerosol and cloud condensation nuclei, Aerosol Sci. Technol., 40, 557-572, 2006.

Spracklen, D. V., Carslaw, K. S., Kulmala, M., Kerminen, V.-M., Mann, G. W., and Sihto, S.-L.: The contribution of boundary layer nucleation events to total particle concentrations on regional and global scales, Atmos. Chem. Phys., 6, 5631-5648, doi:10.5194/acp-6-5631-2006, 2006.

Spracklen, D. V., Carslaw, K. S., Kulmala, M., Kerminen, V.-M., Sihto, S.-L., Riipinen, I., Merikanto, J., Mann, G. W., Chipperfield, M. P., Wiedensohler, A., Birmili, W., and Lihavainen, $\mathrm{H}$.: Contribution of particle formation to global cloud condensation nuclei concentrations, Geophys. Res. Lett., 35, 06808, doi:10.1029/2007GL033038, 2008a.

Spracklen, D. V., Bonn, B., and Carslaw, K. S.: Boreal forests, aerosols and the impacts on clouds and climate, Phil. T. R. Soc. A., 266, 1-11, doi:10.1098/rsta.2008.0201, 2008b.

Spracklen, D. V., Carslaw, K. S., Merikanto, J., Mann, G. W., Reddington, C. L., Pickering, S., Ogren, J. A., Andrews, E., Baltensperger, U., Weingartner, E., Boy, M., Kulmala, M., Laakso, L., Lihavainen, H., Kivekäs, N., Komppula, M., Mihalopoulos, N., Kouvarakis, G., Jennings, S. G., O’Dowd, C., Birmili, W., Wiedensohler, A., Weller, R., Gras, J., Laj, P., Sellegri, K., Bonn, B., Krejci, R., Laaksonen, A., Hamed, A., Minikin, A., Harri- son, R. M., Talbot, R., and Sun, J.: Explaining global surface aerosol number concentrations in terms of primary emissions and particle formation, Atmos. Chem. Phys., 10, 4775-4793, doi:10.5194/acp-10-4775-2010, 2010.

Spracklen, D. V., Carslaw, K. S., Pöschl, U., Rap, A., and Forster, P. M.: Global cloud condensation nuclei influenced by carbonaceous combustion aerosol, Atmos. Chem. Phys., 11, 9067-9087, doi:10.5194/acp-11-9067-2011, 2011a.

Spracklen, D. V., Jimenez, J. L., Carslaw, K. S., Worsnop, D. R., Evans, M. J., Mann, G. W., Zhang, Q., Canagaratna, M. R., Allan, J., Coe, H., McFiggans, G., Rap, A., and Forster, P.: Aerosol mass spectrometer constraint on the global secondary organic aerosol budget, Atmos. Chem. Phys., 11, 12109-12136, doi:10.5194/acp-11-12109-2011, 2011 b.

Squires, P. and Twomey, S.: A comparison of cloud nucleaus measurements over Central North America and the Caribean Sea, J. Atmos. Sci., 23, 401-404, 1966.

Stevens, B. and Feingold, G.: Untangling aerosol effects on clouds and precipitation in a buffered system, Nature, 461, 607-613, doi:10.1038/nature08281, 2009.

Stevens, R. G., Pierce, J. R., Brock, C. A., Reed, M. K., Crawford, J. H., Holloway, J. S., Ryerson, T. B., Huey, L. G., and Novak, J. B.: Nucleation and growth of sulfate aerosol in coal-fired power plant plumes: sensitivity to background aerosol and meteorology, Atmos. Chem. Phys., 12, 189-206, doi:10.5194/acp-12189-2012, 2012.

Topping, D. O. and McFiggans, G.: Tight coupling of particle size, number and composition in atmospheric cloud droplet activation, Atmos. Chem. Phys., 12, 3253-3260, doi:10.5194/acp-12-32532012, 2012.

Twomey, S.: The influence of cloud nucleus population on the microstructure and stability of convective clouds, Tellus, 11, 408411, 1959.

Twohy, C. H. and Anderson, J. R.: Droplet nuclei in nonprecipitating clouds: composition and size matters, Environ. Res. Lett., 3, 045002, doi:10.1088/1748-9326/3/4/045002, 2008.

Twohy, C. H., Clement, C. F., Gandrud, B, W., Weinheimer, A. J., Campos, T. L., Baumgartner, D., Brune, W. H., Faloona, I., Sachse, G. W., Vay, S. A., and Tan, D.: Deep convection as a source of new particles in the midlatitude upper troposphere, J. Geophys. Res., 107, 4560, doi:10.1029/2001JD000323, 2002.

Tunved, P., Hansson, H.-C., Kerminen, V.-M., Ström, J., Dal Maso, M., Lihavainen, H., Viisanen, Y., Aalto, P. P., Komppula, M., and Kulmala, M.: High natural aerosol loading over boreal forests, Science, 312, 261-263, 2006.

Wang, M., and Penner, J. E.: Aerosol indirect forcing in a global model with particle nucleation, Atmos. Chem. Phys., 9, 239-260, doi:10.5194/acp-9-239-2009, 2009.

Wang, J., Cubison, M. J., Aiken, A. C., Jimenez, J. L., and Collins, D. R.: The importance of aerosol mixing state and size-resolved composition on CCN concentration and the variation of the importance with atmospheric aging of aerosols, Atmos. Chem. Phys., 10, 7267-7283, doi:10.5194/acp-10-7267-2010, 2010.

Wex, H., McFiggans, G., Henning, S., and Stratmann, F.: Influence of the external mixing state of atmospheric aerosol on derived CCN number concentrations, Geophys. Res. Lett., 37, 10805, doi:10.1029/2010GL043337, 2010.

Vakkari, V., Laakso, H., Kulmala, M., Laaksonen, A., Mabaso, D., Molefe, M., Kgabi, N., and Laakso, L.: New particle forma- 
tion events in semi-clean South African savannah, Atmos. Chem. Phys., 11, 3333-3346, doi:10.5194/acp-11-3333-2011, 2011.

Venzac, H., Sellegri, K., Laj, P., Villani, P., Bonasoni, P., Marinoni, A., Cristofanelli, P., Calzolari, F., Fuzzi, S., Decesari, S., Facchini, M. C., Vuillermoz, E., and Verza, G. P.: High Frequency New Particle Formation in the Himalayas, P. Natl. Acad. Sci., 105, 15666-15671, 2008.

Venzac, H., Sellegri, K., Villani, P., Picard, D., and Laj, P.: Seasonal variation of aerosol size distributions in the free troposphere and residual layer at the puy de Dome station, France, Atmos. Chem. Phys., 9, 1465-1478, doi:10.5194/acp-9-1465-2009, 2009.

Whitehead, J. D., McFiggans, G., Gallagher, M. W., and Flynn, M. J.: Simultaneous coastal measurements of ozone deposition fluxes and iondine-mediated particle emissions fluxes with subsequent CCN formation, Atmos. Chem. Phys., 10, 255-266, doi:10.5194/acp-10-255-2010, 2010.

Wiedensohler, A, Chen, Y. F., Nowak, A, Wehner, B., Achtert, P, Berghof, M., Birmili, W., Wu, Z. J., Hu, M., Zhu, T., Takegawa, N., Kita, K., Kondo, Y., Lou, S. R., Hofzumahaus, A, Holland, F, Wahner, A., Gunthe, S. S., Rose, D., Su, H., and Pöschl, U.: Rapid aerosol particle growth and increase of cloud condensation nucleus activity by secondary aerosol formation and condensation: A case study for regional air pollution in northeastern China, J. Geophys. Res., 114, 00G08, doi:10.1029/2008JD010884, 2009.

Yli-Juuti, T., Nieminen, T., Hirsikko, A., 5 Aalto, P. P., Asmi, E., Hôrrak, U., Manninen, H. E., Patokoski, J., Dal Maso, M., Petäjä, T., Rinne, J., Kulmala, M., and Riipinen, I.: Growth rates of nucleation mode particles in Hyytiälä during 20032009: variation with particle size, season, data analysis method and ambient conditions, Atmos. Chem. Phys., 11, 12865-12886, doi:10.5194/acp-11-12865-2011, 2011.
Yoon, Y. J. and Brimblecombe, P.: Modelling the contribution of sea salt and dimethylsulfide derived aerosol to marine CCN, Atmos. Chem. Phys., 2, 17-30, doi:10.5194/acp-2-17-2002, 2002.

Yu, F.: A secondary organic aerosol formation model considering successive oxidation aging and kinetic condensation of organic compounds: global scale implication, Atmos. Chem. Phys., 11, 1083-1099, doi:10.5194/acp-11-1083-2011, 2011.

Yu, F. and Luo, G: Simulation of particle size distribution with a global aerosol model: contribution of nucleation to aerosol and CCN number concentrations, Atmos. Chem. Phys., 9, 76917710, doi:10.5194/acp-9-7691-2009, 2009.

Yu, F., Luo, G., Turco, R. P., Ogren, J. A., and Yantosca, R. M.: Decreasing particle number concentrations in a warming atmosphere and implications, Atmos. Chem. Phys., 12, 2399-2408, doi:10.5194/acp-12-2399-2012, 2012.

Yue, D. L., Hu, M., Zhang, R. Y., Wu, Z. J., Su, H., Wang, Z. B., Peng, J. F., He, L. Y., Huang, X. F., Gong, Y. G., and Wiedensohler, A.: Potential contribution of new particle formation to cloud condensation nuclei in Beijing, Atmos. Environ., 45, 6070-6077, 2011.

Zhang, R., Wang, L., Khalizov, A. F., Zhao, J., Zheng, J., McGraw, R. L., and Molina, L. T.: Formation of nano-sized particles of blue haze enhanced by anthropogenic pollution, P. Natl. Acad. Sci., 106, 17650-17654, 2009.

Zhang, R., Khalizov, A., Wang, L, Hu, M., and Xu, W.: Nucleation and growth of nanoparticles in the atmosphere, Chem. Rev., 112, 1957-2011, 2012. 